\title{
Vai, malandra: o despertar ontológico do planeta fome
}

\author{
Armando de Melo Lisboa \\ Universidade Federal de Santa Catarina (UFSC)
}

Recebido: 29/03/2019 Versão revisada (entregue): 24/05/2019 Aprovado: 01/06/2019

\begin{abstract}
Resumo
Empreendimentos populares de todos os tipos perfazem uma progressiva ruptura com a subalternização da maioria do povo brasileiro, levando a uma inserção criativa na vida global, à revelia de projetos cupulistas de nação, conduzidos por pseudos demiurgos salvadores. Este ensaio pressupõe que uma reversão do processo colonial subalternizador esteja em curso, agora, autêntica e completamente, como se fora uma segunda descolonização que, em pleno século XXI, decola com vigor. Aos poucos o povo brasileiro desperta do secular coma étnico e livra-se do domínio dos paradigmas eurocêntricos e patriarcais. Suas iniciativas de buscar uma vida melhor perfazem lutas e processos ontológicos, pois permitem superar o histórico não-ser das maiorias, restabelecendo a plena humanidade de todos.
\end{abstract}

Palavras-chave | Brasil; desenvolvimento territorial; economia popular; negócios inclusivos; ontologia política; segunda descolonização.

Código JEL | J15 J46 Z13

"Vai, malandra"/Go, cheeky girl: the ontological awakening of the Planet Famine

\begin{abstract}
A multitude of grassroots entrepreneurs is embodying a growing disruption of the subordinate condition in which the majority of the Brazilian people is living, leading to their creative inclusion in the global ways of life in clear defiance of the elitist projects of "nation" conducted by pseudo saviors and demiurges. This essay assumes that a reversal of the "subalternizing" colonial process is under way, now authentic and complete, as a second decolonization that in the 21 st century takes off vigorously. Brazilian people, gradually awakes from the centuries-old ethnic coma and gets rid of the dominance of Eurocentric and patriarchal paradigms. Its initiatives on seeking a better life represent struggles and ontological processes because allows us to overcome the non-being of the majorities, restoring the full humanity of all.
\end{abstract}

Keywords | Brazil; inclusive business; political ontology; popular economy; second decolonization; territorial development.

JEL-Code | J15 J46 Z13 


\section{"Vai, malandra": el despertar ontológico del planeta hambre}

\section{Resumen}

Los emprendimientos populares de todo tipo constituyen una progresiva ruptura con la subalternización de la mayoría del pueblo brasileño, llevando a una inserción creativa en la vida global, en ausencia de proyectos cupulistas de "nación" conducidos por pseudos demiurgos salvadores. Este ensayo presupone que una reversión del proceso colonial subalternizador está en curso, ahora auténtica y completamente, como una segunda descolonización que, en pleno siglo XXI, despega con vigor. Poco a poco el pueblo brasilero despierta del secular coma étnico y se libra del dominio de los paradigmas eurocéntricos y patriarcales. Sus iniciativas de buscar una vida mejor constituyen luchas y procesos ontológicos pues permiten superar el histórico no-ser de las mayorías, restableciendo la plena humanidad de todos.

Palabras-clave | Brasil; desarrollo territorial; economía popular; negocios inclusivos; ontología política; segunda descolonización.

Código JEL | J15 J46 Z13

"De que planeta você vem? Do planeta fome, seu Ary"

(Elza Soares, em 1953, no programa de calouros de Ary Barroso, diante de uma plateia que, impressionada com sua esquálida e desarranjada figura, a recebeu com risos e vaias. Após este diálogo, pôde cantar, e então Ary e a plateia, deslumbrados, a ovacionaram de pé).

\section{Inovações libertárias dos condenados da Terra}

As periferias são laboratórios de mundos e a riqueza do Brasil. Não mais os pobres assujeitados e excluídos de certo imaginário e discurso, mas uma ciberperiferia, a riqueza da pobreza (disputada pela Nike, pela Globo, pelo Estado) que transforma as favelas, quilombos urbanos conectados, em laboratórios de produção subjetiva. A carne negra das favelas, os corpos potentes e desejantes, a cooperação sem mando, inventando espaços e tempos outros (na rua, nos bailes, lan houses e lajes), estão sujeitos a todos os tipos de apropriação. É que as favelas e periferias são o maior capital nas bolsas de valores simbólicas do país, pois converteram as forças hostis máximas (pobreza, violência, Estado de exceção) em processo de criação e invenção cultural (BENTES, 2014, p. 8-9).

Uma irrupção extraordinária de riqueza proveniente da diversidade brasileira emerge incontidamente quando se desfazem as castradoras amarras seculares que 
mantêm o império do planeta fome nas terras tupiniquins. Nossas periferias, surpreendentemente transcendem o eterno abandono do Estado e o genocida massacre diário e constante dos corpos morenos e negros perpetrado por sua força policial. Nelas uma pobreza potente, inventa mundos, modas, gírias, linguagem, inventa a sua própria vida (BENTES, 2017). Buscando mapear e compreender este extraordinário fenômeno, apresentaremos, nesta primeira parte, um inventário amostral destas inovações em dez distintas áreas. Em seguida, discutiremos o significado e o alcance das mesmas.

1) Em 1993, Zica Assis e Leila Velez abriam um salão de beleza num fundo de quintal da periferia do Rio de Janeiro voltado aos cabelos crespos e ao público afro. Desabrochada na rede Instituto Beleza Natural, inauguraram, em 2017, uma filial com 600 metros quadrados em Nova York, à qual se somam as 45 unidades de negócios em operação e que mobilizam uma fábrica própria (Cor Brasil Cosméticos) e uma equipe de 3 mil colaboradoras para atender mensalmente em seus salões mais de 130 mil clientes.

Tendo por lemas Beleza Natural: uma fábrica de autoestima; Bonito é ser vocế; Solte seus cachos e Bonito é saber transformar beleza em atitude, Zica Assis já figura entre as dez mulheres de negócios mais poderosas do Brasil, segundo a revista Forbes, enquanto Leila Velez foi escolhida em 2014 pelo Fórum Econômico de Davos como uma das jovens líderes (menos de 40 anos) mais influentes no mundo.

Assim como a Beleza Natural, existem inúmeros outros empreendimentos bemsucedidos que brotam nas periferias urbanas brasileiras. Vale também salientar alguns cases que visam promover e potencializar as mesmas:

Favela Holding': rede de empresas criada por Celso Athayde (RJ, 1963) com a missão de oportunizar negócios para as favelas e seus moradores, especialmente junto a empreendedores comunitários, esforço que levou à fundação da Liga dos Empreendedores Comunitários (LEC).

Agência Solano Trindade: busca fortalecer a economia de cultura criativa, incentivando a produção e difusão de ações culturais populares de forma a alcançarem viabilidade econômica. Para tal, entre outras iniciativas, mantém o Banco Comunitário União Sampaio, onde se emite uma moeda alternativa, o \$ampaio. Atuando na região do Campo Limpo, Capão Redondo e adjacências,

1 Heloiza (Zica) Assis, nascida no Rio de Janeiro em 1961, foi babá aos nove anos, depois empregada doméstica e faxineira. A também carioca Leila (1974), era ex-atendente do McDonald's, sendo promovida à gerente quando tinha 16 anos. (Beleza Natural, 2019).

2 Para fomentar a economia comunitária nas favelas (FAVELA HOLDING, s. d.), Athayde, afrodescendente, ex-morador de rua e ex-coordenador da CUFA, Central Única das Favelas (CUFA, 2019), vem estabelecendo diversas parcerias com empresários e lideranças, entre os quais o rapper MV Bill e Renato Meireles, sendo que com este fundou o instituto de pesquisa Data Favela e publicou Um país chamado favela (2014). 
periferia da cidade de São Paulo, esta espécie de coworking da periferia surgiu em 2012 por iniciativa de Thiago Vinicius (São Paulo, 1989), um dos fundadores do Banco Comunitário, para impulsionar empreendimentos nascidos naquelas comunidades. Ele defende que a periferia não precisa de assistencialismo. Precisa crescer sem depender de ninguém ${ }^{3}$.

2) Iniciativas populares em saúde perfazem uma cativante ebulição que expressa a socio biodiversidade brasileira, ou seja, o conhecimento tradicional passado de geração em geração da nossa inestimável e inigualável biodiversidade, a maior do planeta. Mesmo sendo difícil destacar algo em particular, pois são milhares os casos bem-sucedidos, seguem alguns exemplos:

As Farmácias Vivas, surgidas a partir da experiência do prof. Francisco José de Abreu Mato (CE, 1924-2008) ${ }^{4}$, disseminaram por todo país hortos fitoterápicos, geralmente associados a hospitais. Recolhendo o conhecimento popular em ervas e plantas medicinais, este programa cresce ao enlaçar-se com as Pastorais da Saúde por todos os rincões do Brasil, inspirando a criação da Politica Nacional de Plantas Medicinais e Fitoterápicos, adotada pelo SUS (Sistema Único de Saúde).

Uma iniciativa das Pastorais da Saúde e da Criança merece realce: a Farinha Multimistura, indicada algumas vezes ao Nobel da Paz, por meio de Zilda Arns (SC, 1934-2010), por reduzir substancialmente a desnutrição e a mortalidade infantil brasileira. Criada por Clara Brandão5, a Multimistura difundiu-se em todos os estados brasileiros e em mais 15 países da América Latina, África e Ásia.

${ }^{3}$ Solano Trindade foi um dos criadores da "poesia negra" no Brasil (Agência Popular Solano Trindade, s. d.).

4 Abreu Matos é farmacêutico-químico diplomado em 1945 pela Faculdade de Farmácia do Ceará, um dos embriões da futura Universidade Federal do Ceará (UFC), universidade que ajudou a criar. A partir de inúmeras expedições percorrendo o interior do Ceará e do Nordeste do Brasil, sempre na companhia do prof. Afrânio Fernandes, botânico, coletando espécies vegetais e informações da sabedoria popular/tradicional sobre suas aplicações na saúde, o professor Matos se dedicou a interpretar e transformar em conhecimento científico o conhecimento empírico que absorvia. O projeto Farmácias Vivas foi criado como forma de devolver a ciência das plantas medicinais para a comunidade, levandolhe o ensinamento do seu uso correto.

Nesse intenso trabalho de pesquisa etnobotânica, etnofarmacológica, taxonômica, bibliográfica e experimental (ensaios químicos e toxicológicos), foi selecionada mais de uma centena de espécies vegetais medicinais tendo como critérios imprescindíveis o reconhecimento de seu potencial de eficácia terapêutica e segurança de uso, as quais passaram a integrar o elenco do projeto Farmácias Vivas" (SANTOS; FONSECA, 2012).

${ }^{5}$ Filha de imigrantes japoneses, Clara Takaki Brandão (SP, 1944) formou-se em medicina em 1969 pela USP, com especialização em pediatria e, posteriormente, como nutróloga. No âmbito de um programa de orientação alimentar, desenvolveu a Multimistura a partir de 1975 quando de sua vivência na Amazônia. Em 1983, a Sociedade Brasileira de Pediatria concedeu à Dr. ${ }^{a}$ Clara o prêmio Álvaro Bahia de melhor trabalho contra a mortalidade infantil pelo uso da Multimistura (s. d.). Registre-se que a Multimistura é objeto de uma forte controvérsia com entidades profissionais da área da nutrição. 
Também na linha dos fitoterápicos, sobressai-se a Farmacopéia do Cerrado (DIAS; LAUREANO, 2008), resultado de pesquisa de centenas de raizeiros e raizeiras que formaram, em 1999, a Articulação Pacari, uma rede de grupos comunitários que praticam a medicina tradicional no Cerrado.

Progressivamente, impõe-se o movimento pela humanização do parto, despontado a partir dos anos 1970 (quando, não por acaso, ecoava a crítica de Ivan Illich ao excesso de medicalização da saúde) com o Prof. José Galba Araújo (CE, 1917-1985) ${ }^{6}$, que apoiava as práticas tradicionais de parteiras e índios, e vem a desembocar na Rede pela Humanização do Parto e do Nascimento (Rehuna), fundada em 1993. Num país que detém até o presente o triste recorde de cesarianas, a luta pelo parto natural tem ainda imensa relevância e promete, infelizmente, uma longa duração.

Ainda no Ceará, e daqui irradiado para o mundo, surge o movimento da Terapia Comunitária, cujo pioneiro é Adalberto Barreto ${ }^{7}$. Iniciada numa favela em Fortaleza em 1987, hoje estende-se pelo Brasil, por meio das redes Associação Brasileira de Terapia Comunitária Integrativa (ABRATECOM) ${ }^{8}$ e Movimento Saúde Mental Comunitária (MSMC) ${ }^{9}$, e pela América Latina, África e Europa, como a Association Europeenne de Therapie Communautaire Integrative ${ }^{10}$.

Por ser de domínio público, este conjunto de práticas e conhecimentos é vivenciado cotidianamente de forma generalizada, beneficiando multidões. Dentre as políticas nacionais moldadas por estas experiências, também se evidencia o relevante e consolidado Programa de Agentes Comunitários de Saúde (PACS), no âmbito do Ministério da Saúde. Mas existem inúmeras instituições voltadas para um público de baixa renda que aplicam esta visão global e holística em saúde de

${ }^{6}$ Médico obstetra e professor da UFC, Galba de Araújo foi diretor da Maternidade Escola Assis Chateaubriand da Universidade Federal do Ceará de 1964 a 1985. Desde 1999, o Ministério da Saúde outorga o "Prêmio Galba de Araújo" para condecorar profissionais e instituições dedicadas à humanização da atenção à mulher, ao recém-nascido e que estimulam o parto natural e o aleitamento materno.

7 Premiado internacionalmente, Barreto é professor no curso de Medicina da UFC, possuindo doutorados em psiquiatria e antropologia na França, além de graduação em Filosofia e Teologia em Roma em 1976.

8 ASSOCIAÇÃO BRASILEIRA DE TERAPIA COMUNITÁRIA - ABRATECOM. Quem somos. s. d. Disponível em: http://www.abratecom.org.br/QuemSomos/Abratecom/.

9 MOVIMENTO SAÚDE MENTAL COMUNITÁRIA. Website. Disponível em: $<$ https://msmc.org.br/>.

10 ASSOCIATION EUROPEENNE DE THERAPIE COMMUNAUTAIRE INTEGRATIVE. Website. 2012. Disponível em: <https://www.aetci-a4v.eu/>. 
forma intensiva e profissionalizada, atendendo com sucesso casos agudos e já desenganados, como o Instituto Ecumênico Popular L'amigo (IEP) ${ }^{11}$, em Penha (SC).

3) Também na periferia de Fortaleza (CE), no bairro Palmeira, nasceu o Banco Palmas, talvez o mais expressivo fenômeno da vertente popular da economia solidária brasileira. No âmbito da luta pela melhoria do que era, então, uma das mais carentes áreas da capital cearense, surge a Associação de Moradores do Conjunto Palmeira (ASMOCONP). Esta, sob a liderança de Joaquim Melo (CE, 1962), diante da carência de recursos financeiros, criou em 1998 o Banco Palmas, adotando de imediato algumas práticas financeiras para o desenvolvimento local, tais como um cartão de crédito próprio, o PalmaCard, e a emissão de sua própria moeda, o Palmares. Desse embrião amadureceu a Rede Brasileira de Bancos Comunitários, hoje formada por 103 bancos comunitários ${ }^{12}$.

4) Os bem-sucedidos empreendimentos camponeses de base familiar e agroecológicos também são legião. Na contramão da modernização dolorosa (SILVA, 1982), que aprofundou a concentração fundiária, o êxodo rural, a exclusão social e o uso de venenos, convergindo com dinâmicas globais de recampesinação, eles são frutos da ampla luta e mobilização em prol da agricultura sustentável e familiar, a qual impacta amplamente à sociedade brasileira, possibilitando um crescente consumo de produtos orgânicos. Entre eles, sobressai-se a Associação dos Agricultores Ecológicos das Encostas da Serra Geral (Agreco) ${ }^{13}$, fundada em 1996 e hoje gerando um faturamento equivalente à metade do orçamento do seu município de origem, Santa Rosa de Lima (SC), tornando-se a principal referência do mesmo. Vem desenvolvendo agroindústrias rurais de pequeno porte e o premiado programa de agroturismo Acolhida na Colônia, o qual ganhou vida própria e mantém-se como um dos principais parceiros da Agreco $^{14}$.

11 INSTITUTO ECUMÊNICO POPULAR L'AMIGO - IEP. Website. Disponível em: $<$ https://ieplamigo.com.br/>.

12 http://www.institutobancopalmas.org/. O Banco Palmas gestou, dentro do bairro, uma rede de empresas e Inúmeros projetos socioeconômicos, tais como: PalmaTur (promoção do turismo no Conjunto Palmeira); Palma Fashion (confecções e calçados); Palma Limpe (materiais de limpeza; Loja Solidária e Feira (para comercializar os produtos fabricados no bairro); PalmaNatus (sabonetes e fitoterápicos); Bairro Escola de Trabalho (capacitação profissional); Incubadora Feminina; Companhia Bate Palmas (empreendimento de educação, arte e cultura, com ênfase na música); Curso de Consultores Comunitários; Academia de Moda Periferia; PalmaTech (escola para capacitação e gestão de empresas); Escola Popular Cooperativa Palmas (pré-vestibular); Comício Inverso (evento na praça pública no período eleitoral onde a população do bairro sobe no palanque para relatar seus problemas e apontar soluções, e os candidatos a prefeito e vereadores escutam sentados).

13 ASSOCIAÇÃO DOS AGRICULTORES ECOLÓGICOS DAS ENCOSTAS DA SERRA GERAL. Website. Disponível em: <http://www.agreco.com.br/>.

14 Outras organizações parceiras da Agreco e surgidas a partir da mesma são: CEFAE - Centro de Formação em Agroecologia Jean Yves Griot (www.cfaeagroecologia.com); DoDesign-s (www.dodesigns.com.br) - escritório especializado em design para negócios orgânicos, comércio justo, alimentos gourmet e projetos ligados à sociobiodiversidade. Também já premiado nacional e internacionalmente; Boa Vista 
Da mesma região da Agreco, mas atuante em toda a Região Sul, advém a Rede Ecovida de Agroecologia ${ }^{15}$. Foi erguida em 1998 para aglutinar dezenas de organizações, movimentos sociais, centenas de cooperativas e grupos de agricultores que constroem uma alternativa ao modelo de agricultura dominante no país. Ela criou o Sistema Participativo de Garantia, uma forma de certificação coletiva que responsabiliza os produtores e que configura uma tecnologia social que reduziu imensamente os custos de auditoria e certificação de orgânico, hoje disseminada mundialmente.

Este revigoramento do campesinato também está presente na Região Sisaleira, em pleno coração da Bahia e do Cerrado brasileiro, onde cresceu a cooperativa APAEB - Associação de Pequenos Agricultores do Estado de Bahia. Ela foi fundada em 1980 para produzir e comercializar tapetes e carpetes de sisal de forma a desenvolver sustentavelmente a região. $\mathrm{Na}$ transformação do sisal, produzido por cerca de 1.200 agricultores, a APAEB emprega mais de 900 pessoas no município de Valente ${ }^{16}$.

5) As vozes dos povos indígenas ecoam cada vez mais alto, não apenas na luta pelos seus direitos e afirmação das suas culturas, mas também por meio da qualidade com que estão a gerar renda, riqueza e conhecimento. Com diversos pontos comerciais de venda (como nas lojas da Tok\&Stok e Pão de Açúcar), o belíssimo artesanato do povo Baniwa (Alto Rio Negro/AM) é ofertado em todo Brasil e até no exterior. Este caso bem-sucedido de comércio justo é fruto do cuidadoso projeto Arte Baniwa ${ }^{17}$, gestado na parceria desse povo com o ISA Instituto Socioambiental. Na região de São Gabriel da Cachoeira, conhecida como "Cabeça do Cachorro" (pelo seu formato no mapa do Brasil), maior e mais relevante território indígena brasileiro, os 23 povos lá presentes organizam-se

SS Ltda - empresa voltada para a geração de projetos inovadores e sustentáveis social, ambiental e economicamente; AMESG - Associação de Meliponicutores das Encostas da Serra Geral de Santa Catarina - entidade criada para promover as abelhas nativas (sem ferrão) e difundir a produção e uso do mel de melíponas; Editora O Ronco do Bugio - instituição criada para apoiar o jornal comunitário CANAL SRL, produzido, em boa medida, por jovens agricutores(as) das comunidades rurais. Também estimulou a implantação da filial brasileira da Ecocert (http://brazil.ecocert.com/), certificadora de origem francesa responsável pela inspeção da produção orgânica dos produtos da Agreco (ACOLHIDA NA COLÔNIA, s. d.).

15 Além da presença em mais de uma centena de feiras e lojas, a Rede Ecovida possui box para a venda atacadista de produtos orgânicos na Ceasa/SC, otimizando a comercialização e os ganhos de escala da agricultura familiar. (REDE DE AGROECOLOGIA ECOVIDA, s. d.)

16 A APAEB vem investindo em projetos socioeducativos e econômicos, tais como: produção queijo e iogurte com leite de cabra; apicultura; Escola Familiar Agrícola; Rádio da Cidadania; Reflorestamento; Centro de Informática; Clube Social e TV Valente (ABAEP, 2014).

${ }^{17}$ ARTE BANIWA. Website. Disponível em: <https://www.artebaniwa.org.br/>. 
desde 1987 em torno da FOIRN - Federação das Organizações Indígenas do Rio Negro. ${ }^{18}$

Brilha também o projeto Video nas aldeias ${ }^{19}$, premiado nacional e internacionalmente. Surgido em 1986 com o trabalho de Vincent Carelli (França, 1953) no Centro de Trabalho Indigenista, este projeto utiliza recursos audiovisuais para fortalecer a cultura e a identidade dos povos nativos. Ailton Krenak (MG, 1953), cofundador da União das Nações Indígenas (1980) e uma das principais presenças indígenas nas discussões da Assembleia Constituinte, idealizou uma amostra de filmes indígenas, a Aldeia SP, que em 2016, em sua segunda edição, denominou-se "Bienal de Cinema Indígena", apresentando 57 filmes recentemente produzidos por eles, com uma forte amostra de produção feminina.

6) Dentro do vigoroso ramo da arquitetura e construção brasileiras, registro apenas a premiação há pouco obtida por um edifício erguido com base nas tecnologias indígenas. Este projeto logrou o prêmio BREEAM Awards 2018 como melhor edifício sustentável das Américas ${ }^{20}$ face seu conforto térmico, utilização máxima da iluminação natural e da água de chuva. Trata-se do Centro Sebrae de Sustentabilidade (CSS), em Cuiabá (MT), projetado pelo arquiteto José Portocarrero. Destaco da notícia:

As casas indígenas resistem muito mais, não são derrubadas pelo tempo, porque são construções aerodinâmicas e reduzem em $30 \%$ a força do vento. O ar passa ali como respiração", afirma Portocarrero, que já visitou 28 aldeias indígenas em suas pesquisas. "Não foi um índio ou um arquiteto, mas gerações de indígenas que desenvolveram essas tecnologias, desde o desenho até os materiais de construção de uma estrutura espacial.

7) No meio do oceano de práticas educativas inclusivas, a rede de cursos prévestibular popular desponta como uma das mais relevantes. Superando a exclusividade dos caros cursinhos, ela oferece para um público de baixa renda cursos de custo reduzido ou gratuitos, contribuindo decisivamente para romper as barreiras que excluíam o pobre e o negro da escola pública e assim reduzir a abissal desigualdade educacional, especialmente no acesso à universidade pública. Sem esperar pelas urgentes correções do falido sistema educacional, tal esforço

18 FOIRN - FEDERAÇÃO DAS ORGANIZAÇÕES INDÍGENS DO RIO NEGROWebsite. Disponível em: <https:/ foirn.org.br/>.

19 VÍDEO NAS ALDEIAS. Website. Disponível em: $<$ http://www.videonasaldeias.org.br/2009/index.php>.

20 O BREEAM Awards 2018 é concedido pela mais antiga empresa certificadora de construções sustentáveis no mundo, sediada em Londres (CAU, 2018). 
permite mitigar disfunções estruturais, desencadeando, mesmo assim, relevantes e sinérgicas dinâmicas de melhoria na vida de muitos.

Entre os anos 1970 e 1980, surgiram as primeiras e isoladas experiências de cursinhos populares. Na década de 1990, elas alastram com vigor, fazendo-se presentes em todos os rincões do país. Não há um levantamento recente, mas dados de 2001 dão conta da existência de 800 núcleos em todo país (ZAGO, 2008: 151). Na Baixada Fluminense, por exemplo, um dos pioneiros foi o cursinho Educafro (1992) ${ }^{21}$, organização fundada e dirigida por frei David dos Santos (MG, 1952) e mantida pelo Serviço Franciscano de Solidariedade. Na Baixada também aflorou o Movimento de Cursos Pré-Vestibulares para Negros e Carentes $(\mathrm{PVNC})^{22}$, rede com diversos núcleos de ensino.

Também buscando reverter o quase nulo acesso dos indígenas à universidade, um espaço tradicionalmente ligado as elites e praticamente anti-indígena, destacaramse a partir dos anos 2000 tanto o esforço dos cursos de formação de professores indígenas ${ }^{23}$ quanto a via das ações afirmativas (política de cotas e de permanência). Tais exemplos são conquistas do movimento índio, sendo, portanto, cursos e políticas pensadas e elaboradas com e não para os povos indígenas.

Para além do esforço de inclusão indígena nas Instituições de Ensino Superior (IES), também existe uma ampla construção de experiências de educação indígena em todos os níveis, especialmente a da escola indígena bilíngue e intercultural, valorizadora da experiência de cada povo, diferenciada daquela que negou e silenciou suas culturas. Foi o advento desta escola indígena que trouxe a demanda por formação dos professores índios, atores decisivos neste processo de mudança da escola colonialista. Na luta pelos direitos indígenas e fortalecimento de suas culturas, a educação tem enorme relevância, sendo fundamental na construção de relações pós-coloniais ${ }^{24}$. A educação indígena contribui imensamente para "reenraizar os jovens em suas culturas tradicionais", retomando tradições "por

21 EDUCAFRO. Website, 2019. Disponível em: <http://www.educafro.org.br/site/conhecaeducafro $/>$.

22 MOVIMENTO PVNC - PRÉ-VESTIBULAR PARA NEGROS E CARENTES. Website. Disponível em: <http://www.sentimentanimalidades.net/pvnc/index.htm>.

${ }^{23}$ Em 2016, em todo país contavam-se 27 cursos de licenciatura indígena. Além do já generalizado ingresso por cotas (5\% para índios), sete universidades públicas (1 estadual) adotaram o vestibular indígena, um processo seletivo direcionado. A Universidade Federal de Roraima é a única que conta com um instituto de formação superior indígena, o Insikiran (UFRR, s. d.) que oferece três cursos de formação em nível de graduação para povos tradicionais, além das vagas nos demais cursos. Cabe também realçar o Rede de saberes, um programa de permanência de indígenas no ensino superior da Universidade Católica Dom Bosco (UCDB/MS), financiado pela Fundação Ford. Reunindo parcerias entre a UCDB, UEMS, UFGD e UFMS, que desde 2005 apoia a trajetória dos acadêmicos indígenas dentro das IES.

${ }^{24}$ No dizer do moicano Taiaiake Alfred (apud LISBOA, 2017, p. 239), intelectual indígena canadense, $a$ educação é o caminho para o conbecimento, a arma que nossos guerreiros precisam no Século XXI. Enfrentar o Estado sem uma educaşão boje seria como entrar em uma batalha contra a cavalaria com arco e flechas. 
anos reprimidas pelo ensino oficial" (LISBOA, 2017, p. 239-247). Mais do que programas de acesso às IES, buscam-se formas pedagógicas adequadas, usar seus idiomas, elaborar materiais didáticos culturalmente corretos, promover valores e conhecimentos não eurocêntricos. Ou seja, tratam-se de programas que ambicionam a construção de uma outra universidade, intercultural.

Outra valiosa ação educativa includente é o projeto Novos Caminhos ${ }^{25}$, voltado para a formação profissional e inserção no mundo do trabalho dos adolescentes abrigados em Programas de Acolhimento que não têm perspectivas de retornar à família ou de serem adotados. Como o acolhimento nesses programas encerra-se ao completarem 18 anos, urge prepará-los para o exercício da autonomia. Buscando isso, uma parceria entre o Tribunal de Justiça de Santa Catarina, a Associação dos Magistrados Catarinenses e a Federação das Indústrias do Estado de Santa Catarina implantou em 2013 o Novos Caminhos, oferecendo aos jovens abrigados a partir dos 14 anos cursos profissionalizantes e outras atividades complementares visando a sua qualificação e encaminhamento para o trabalho.

Ainda na área do acesso à educação, vale salientar o F12326. Criado em 2010 por Fernando Botelho (SP, 1968), trata-se de um empreendimento social que oferece um software barato ( $8 \%$ do preço do convencional), cursos online e de serviços de consultoria em três idiomas para a inclusão de cegos ou pessoas com deficiência visual. O empreendimento conta com usuários em mais de 20 países.

Também não poderíamos deixar de mencionar a 4you2, startup que democratizou o ensino de Língua Inglesa oferecendo cursos baratos (reduz em até 1/7 o custo) nas periferias de São Paulo, Minas Gerais e Paraíba. Fundada pelo estudante Gustavo Fuga (RJ, 1993) em 2011, ela oferece não apenas o ensino de idiomas, mas experiências transculturais acessíveis e de qualidade para a base da pirâmide social. Todos os professores são estrangeiros (intercambistas ou profissionais refugiados), provenientes de 40 países, que moram com uma família na comunidade em que lecionam. Com turmas de no máximo 15 alunos, por suas salas já passaram mais de $10 \mathrm{mil}^{27}$ estudantes.

\footnotetext{
25 http://amc.org.br/novoscaminhos/programa-novos-caminhos/

${ }^{26}$ F123. Website. Disponível em: <https://f123.org/>.

27 Como muitos jovens empreendedores, Gustavo quer fazer a diferença e espalhar conhecimento: Dinheiro é consequência, mas não é objetivo final, não é isso que motiva a gente. A gente quer ver as coisas diferentes. Eu quero ver o mundo diferente quando eu morrer. Não quero deixar o mundo igual, não vim pra Terra pra isso (MUNARO, 2017). Vale transcrever o Manifesto da You2: Somos mais que uma escola de inglês. Somos encurtadores de fronteiras. Construímos pontes entre você e o mundo. Somos apaixonados por ideias. Somos loucos por criatividade. Somos ávidos por INOV AÇÃO. O que nos dá brilho no olho é trazer para a sala de aula uma amostra do mundo que gostariamos de viver: um lugar de debate (e menos imposiçôes), diverso e que todos aprendam continuamente. Queremos criar conexões verdadeiras. Não ensinamos: construimos e produzimos conbecimento em conjunto. Aqui não tem espaço para preconceito: somos extremamente comprometidos com o conceito de diversidade cultural. PROVAMOS TODOS OS DIAS QUE O MUNDO É MUITO MAIOR DO QUE VOCE OUSA PENSAR. Vamos além: cuidamos da sua desenvoltura no idioma, mas cuidamos também do seu crescimento cultural. E nos orgulbamos disso.
}

14 | Revista Brasileira de Desenvolvimento Regional, Blumenau, 7 (1), P. 5-42, 2019 
8) A tradicional cultura do bambu é aperfeiçoada e difundida ainda mais por meio das bambuzerias, entre as quais desponta a CERBAMBU - Centro de Referência do Bambu e das Tecnologias Sociais, em Ravena/ $\mathrm{MG}^{28}$, tocada por Lúcio Ventania (MG, 1966), um dos principais representantes da qualificação e popularização do uso do bambu no Brasil. É um típico inovador brasileiro que integra tecnologia, design e sociedade com seu talento de perceber espaços e recriá-los como oportunidades sustentáveis. Sua versatilidade em múltiplos usos - construção civil, artesanato, móveis, alimentação, medicina, vestuário, decoração, utilitários, brinquedos, proteção ambiental etc. - e outras características - leveza, flexibilidade, resistência, renovabilidade, durabilidade (quando tratado), abundância, gratuidade, rapidez (de crescimento) - com altíssima produtividade, moldabilidade, beleza, sustentabilidade (não gera impacto ambiental, ao contrário: é utilizado para evitar a degradação de solos e para absorver carbono) - o bambu é, literalmente, uma planta de mil utilidades e única em todo universo. O bambu está apto a gerar uma potente cadeia produtiva inclusiva. Não há barreiras de capital no seu uso: em geral bastam ferramentas simples, como o canivete, trabalhando-se artesanalmente, sendo suas técnicas de domínio público, gerando um novo e ecológico ciclo econômico de prosperidade limpa, leve e bela.

9) Dentre as incontáveis experiências de reciclagem de resíduos, releva-se a Associação dos Catadores de Papel, Papelão e Material Reaproveitável (ASMARE) ${ }^{29}$. Fundada em 1990, culminação do esforço da Pastoral de Rua da Arquidiocese de Belo Horizonte com um dos segmentos mais excluídos da sociedade, a ASMARE vem, por meio de parcerias com a prefeitura, inserindo progressivamente $\mathrm{O}$ catador no mercado da reciclagem por meio de coleta seletiva. Reciclando vidas e sonhos, sua fundadora, Maria das Graças Marçal (MG, 1950), conhecida como Dona Geralda, ganhou em 1999 prêmio da UNESCO para quem se destacou em projetos de alcance social. Foi eleita pela revista Claudia, em 2009, uma das cinco mulheres do ano.

10) Incidindo na linha de negócios inclusivos com intenso uso de Tecnologia da Informação (TI), cabe registrar os seguintes casos e organizações brasileiras que nela se inserem e estão a difundi-la:

Acreditamos em relações transparentes, sem letras pequenas. Trabalhamos diariamente para sermos uma organização bumanizada e que realmente se importa com você, com seu tempo e com sua rotina. PENSAMOS GRANDE, PENSAMOS GLOBAL. Por isso temos como bandeira a democratização e o acesso à educação. Idealistas e megalomaniacos? SIM, mas com profundo senso de qualidade e respeito ao aluno. Queremos mudar a sociedade. Mas, principalmente, queremos que todos facam parte dessa MUDANCA: que ela seja de baixo pra cima e que ela seja pra você também. https://4y2.org/pt/home-page/

${ }^{28}$ CERBAMBU RAVENA - CENTRO DE REFERÊNCIA DO BAMBU E DAS TECNOLOGIAS SOCIAIS. Website. Disponível em: <https://www.cerbambu.org.br/>.

${ }^{29} \mathrm{http}: / /$ asmare.org/ 
ARTEMISIA: organização fundada em 2004 para apoiar empreendedores que querem transformar o Brasil com negócios lucrativos que incluam pessoas de baixa renda ${ }^{30}$. Buscando oferecer soluções escaláveis para problemas sociais da população de baixa renda", entende ser parte da sua missão "criar uma nova geração de negócios que rompam com os padrões precedentes e (re)signifiquem o verdadeiro papel que os negócios podem ter na construção de um país com iguais oportunidades para todos (MARQUES, 2014). Seu Manifesto explicita que

\begin{abstract}
Entre ganhar dinheiro e fazer a diferença, escolhemos ficar com os dois. [...] Integrar negócios e impacto social é nossa crença fundamental. [...] Estamos construindo uma nova geração de negócios para resolver os dois lados de uma mesma questão. E porque queremos construir os negócios do futuro, não temos medo de assumir riscos para romper com padrões e transformar o que já não pode mais seguir como está. [...] E, acima de tudo, cuidaremos para [...] garantir a construção de negócios que genuinamente melhorem a vida de centenas, milhares, milhões ou até mesmo bilhões de pessoas ${ }^{31}$.
\end{abstract}

Escola Popular de Comunicação Crítica (ESPOCC): criada em 2005 pelo Observatório de Favelas, no conjunto de favelas da Maré (RJ), a ESPOCC busca introduzir jovens e adultos das periferias no campo da comunicação, visando potencializar sua ação crítica e transformadora. Para tal, trabalha com linguagens e técnicas da Publicidade Afirmativa, a que não visa fins estritamente comerciais, pois promove valores de sociabilidade, a cultura e o empreendedorismo comunitário e socioambiental ${ }^{32}$.

Gastromotiva (2019): "Não basta a comida ser boa, ela precisa também fazer bem para a sociedade". Trabalhando com o conceito de gastronomia social, ou seja, a comida como agente de transformação, a Gastromotiva é uma organização que busca transformar a vida de pessoas em vulnerabilidade social por meio da comida, oferecendo, para tal, cursos de cozinha e outras atividades. Iniciada em 2006 pelo chef David Hertz (PR, 1974), aproveitando sobras não comercializáveis em Ceasas, feiras e supermercados, ela usa a gastronomia como ferramenta promotora de educação, empregabilidade e renda. Tem a colaboração de renomados chefs, tais como Alex Atala (SP, 1968), o qual ministrou cursos junto ao projeto "Gastronomia nos Presídios", entre outros. Sua filosofia é: "Não basta apenas ensinar a cozinhar. Queremos formar cidadãos mais conscientes e

\footnotetext{
30 ARTEMISIA. Quem somos. Disponível em: <https://artemisia.org.br/quemsomos/>.

31 ARTEMISIA. Sobre a Artemisia. Disponível em:

$<$ http://artemisia.org.br/conteudo/artemisia/nosso-manifesto.aspx $>$.

32 http://www.espocc.org.br/a-espocc/como-funciona/
} 
preparados para o mercado de trabalho. Contribuindo com seu crescimento pessoal, profissional e também das comunidades onde vivem" 33 .

BlackRocks: iniciativa de Maitê Lourenço (SP, 1984) que, considerando que a maioria dos microempreendedores do Brasil é negra, tem por missão

\begin{abstract}
aumentar a diversidade racial no ecossistema empreendedor brasileiro com o apoio a profissionais - negras e negros - para atuarem como executivos, programadores/desenvolvedores em empresas de tecnologia e/ou como fundadores de startups inovadoras ${ }^{34}$.
\end{abstract}

Protagonizo: plataforma que visa ampliar a presença de afrodescendentes nas grandes empresas, criada por Alexandra Loras (França, 1977). Com a filosofia de que a diversidade é boa para os negócios, pois pesquisas apontam que empresas com diversidade étnico-racial aumentam a rentabilidade de 35\% a 40\%, ela atua especialmente junto aos departamentos de recursos humanos das grandes empresas, quebrando preconceitos presentes nestes setores e aproximando-os de talentos negros poliglotas egressos de renomadas universidades ${ }^{35}$.

EMPREGUEAFRO: Fundada por Patrícia Santos de Jesus (SP, 1980) em 2004, também com a metodologia de aliar os recrutadores e profissionais de recursos humanos ao processo de inclusão, ela diz que 90\% das empresas que buscam seus serviços são americanas, onde há negros no alto escalão. "Quando eles visitam o Brasil, não entendem como $50 \%$ da população é negra mas não é representada na empresa, e começam a fazer pressão." (ARCOVERDE, 2017). ${ }^{36}$ Hoje, entre as 150 maiores empresas do país, 20\% estão em sua carteira de clientes.

$V$ ale do Dendê: uma holding social que fomenta o empreendedorismo na periferia e no centro histórico de Salvador (Bahia). Considerando que "soluções criativas surgem a partir de situações de vulnerabilidade", ela nasceu a partir da iniciativa de Paulo Rogério Nunes (Salvador, 1981), e atua investindo prioritariamente em projetos protagonizados por mulheres, jovens e afrodescendentes por meio da "Aceleradora Vale do Dendê". Presta serviços de consultoria (Vale Consulting) e também trabalha na formação de talentos oferendo cursos e treinamentos (Vale do Dendê Academy) ${ }^{37}$.

\footnotetext{
${ }^{33}$ GASTROMOTIVA. Website, 2019. Disponível em: <http://gastromotiva.org/>.

${ }^{34}$ BLACKROCKS. Nossa Missão. Disponível em: <http://www.blackrocks.com.br/\#nossa-missao>.

35 PROTAGONIZO.COM. Website. Disponível em: <https://www.protagonizo.com/>.

36 Mais informações em: EMPREGUE AFRO. Website. Disponível em: $<$ https://empregueafro.com.br/wp/>.

37 VALE DO DENDÊ. Website. Disponível em: <http://www.valedodende.org/>.
} 
Por fim, recentemente uma notícia extraordinária (LIMA, 2018) desvelou que, na contramão da assustadora retração econômica e descenso social ocorrida generalizadamente no ano de 2017, 464 mil negros e pardos ascenderam para as classes A e B. Com exceção da classe mais pobre, todas as faixas sociais tiveram redução. Cerca de 800 mil pessoas deixaram as classes mais altas. Apesar desta diminuição, a participação da população de cor ampliou-se. Tal fato excepcional não decorre de um único fator mas de inúmeros. Inclusive, a recente política pública de ações afirmativas e cotas étnico-raciais. Todavia, como esta ainda começa a produzir seus primeiros frutos, ela pouco explica a escala ocorrida (quase 500 mil pessoas) de inserção nas faixas de mais alta renda.

Tal fenômeno representa uma mudança cultural e econômica profunda, para a qual, sem dúvida, contribuiu a militância negra contra o racismo e em prol da sua afirmação identitária. Porém, neste cenário, tal tipo de ascensão e na amplitude posta, é opera e efetivada por meio de um amplo e meticuloso trabalho de uma miríade de organizações fomentando o empreendedorismo e a inclusão dos afrodescendentes, como os últimos casos citados e nos tópicos 1 e 7 . Configurando um padrão bottom-up (processos advindos de baixo) aberto e emergente, elas tiveram um protagonismo fundamental. Até por ocorrer na contramão de um processo recessivo e também se sustentar em elevações na produtividade conectadas com os novos metabolismos econômicos da terceira revolução industrial, estamos diante de um tipo de inclusão que promete ser duradouro. Isto se diferencia profundamente da frágil inclusão dos mais pobres apenas pelo consumo derivado de transferências diretas e facilidades creditícias recentemente ocorridas com as políticas socioeconômicas petistas, que rapidamente estancou e até retrocedeu. Talvez esteja em curso um verdadeiro fim da eterna sujeição e subalternidade de nosso povo, como examinaremos a seguir.

\section{Descolonização, parte segunda}

"No Brasil estamos vergados sob o jugo do colonialismo mental. Nossas ideias, como nossas instituições, em geral, não são nossas, são importadas. Importamos as correntes com que nos manietamos [...]. Mas o Brasil provoca porque seu traço mais importante é a vitalidade: desmedida, assombrosa, anárquica. A vitalidade não é apenas fato, é também base para a definição de um ideal [...]. É a aposta na grandeza dos homens e das mulheres comuns"

(Roberto M. Unger).

Leilas e Zicas; Celsos e Adalbertos; Joaquins e Baniwas; Lúcios e Geraldas; Davis e Fernandos. Além destes personagens que estão a moldar o Século XXI, existem inúmeros heróis anônimos que (re)constroem este imenso país aproveitando de pequenas brechas e oportunidades, configurando milhões de empreendedores a 
formar um tsunami econômico e uma autêntica metamorfose, superior às mega e midiáticas revoluções conduzidas por super-heróis ${ }^{38}$.

A amplitude da riqueza advinda das inovações institucionais, tecnologias sociais, invenções democráticas e negócios inclusivos forjadas no Brasil é incomensurável e ultrapassa qualquer tentativa de contabilizá-las e descrevê-las. Para além das já arroladas, deparamo-nos ainda com uma infinidade de bem-sucedidas práticas, seja em outros setores e redes (como as da justiça reparativa, da permacultura e da educação biocêntrica (CAVALCANTE, 2006; CULTURA BIOCÊNTRICA, 2007), seja provinda de lutas e organizações (como o movimento da biciletada; a experiência metodológica do MOC - Movimento de Organização Comunitária ${ }^{39}$; ou da Rede Brasileira de Incubadoras de Cooperativas Populares).

Contra tudo e todos, todavia, esta força que se faz cada vez mais presente no cenário brasileiro contemporâneo, moldando-o decisivamente, emerge num processo praticamente autoespontâneo e completamente descentralizado, superando seculares barreiras de preconceito, classe e geografia.

\section{O desencontro com o desenvolvimentismo: apadrinhando as campeãs da nação}

"Se a Copa do Mundo era para ter sido a apoteose do projeto do Brasil Grande lulista, o 7 a 1 é o seu supremo anticlímax"

(Moysés Pinto Neto).

"País desenvolvido não é aquele em que pobre anda de carro, mas onde rico anda de transporte público" (consigna nas manifestações brasileiras de junho de 2013).

Os recentes governos petistas (14 anos contínuos no plano federal e diversos outros em níveis estadual e municipal), apesar de terem contado com amplo respaldo de base popular, inclusive com parte de seus quadros de militância

\footnotetext{
38 Uma pequena amostra destes notáveis anônimos são os agraciados em 2017 com o Prêmio Veja-se, o qual honrou cidadãos que, longe dos holofotes, são agentes de transformação da sociedade brasileira: Roberto Nogueira (Brisanet); Joice Toyota (Vetor Brasil); Flávia Rezek (Escola Municipal Rio de Janeiro, na Favela do Jacaré); Priscila Miranda (Associação Presente); Maitê Lourenço (BlackRocks); Sylvia Guimarães (Associação Vagalume).

39 O MOC (2015) é liderado por Abdalaziz de Moura (PE, 1944), também fundador do Serta - Serviço de Tecnologia Alternativa (SERTA, s. d.). Em 2017, foi um dos premiados na $11^{a}$ edição do prêmio Trip Transformadores. Ainda sobre Moura: http://www.cartacapital.com.br/sociedade/o-mel-as-cabras-afarinha-e-a-avo
} 
partidária, não tiveram coragem - ou capacidade - de construir e mostrar ao mundo um caminho alternativo à rota ocidental de desenvolvimento (uso intensivo de capital e energia; produção em grande escala e culto ao gigantismo; dinâmica de extroversão - voltado para além das fronteiras, com traços imperialistas - subordinação das maiorias, passiva, depreciativa e folcloricamente consideradas, e indiferença para com a exploração abusiva dos recursos naturais). Ao contrário, optaram descarada e interesseiramente por tocar grandes obras com as maiores empreiteiras do país de forma a asfaltar (literalmente, inclusive retomando antigas ideias da ditadura militar de cortar a Amazônia com estradas e imensas hidrelétricas) o caminho para tornar o Brasil, gigante por natureza, um gigante econômico e político de fato.

Estas grandes obras ergueram-se especialmente em torno do Programa de Aceleração do Crescimento (PAC), sua principal política econômica, de corte desenvolvimentista. Fiel ao lema positivista e decimonômico ${ }^{40}$ Ordem e Progresso, reabilitaram em pleno Século XXI o então ultrapassado ideário do crescimento econômico, acelerando-o e assim escancarando um debochado retrocesso frente à internacionalmente consagrada ideia de que desenvolvimento significa muito mais que mero crescimento. Para acalmar e manter sob controle a militância, políticas residuais foram destinadas para apoiar estes setores populares, com resultados, em geral, pífios, mas com o efeito simbólico de edulcorar com autênticas cerejas o bolo desenvolvimentista.

A aliança petista pôs em curso um projeto neodesenvolvimentista caracterizado por consolidar oligopólios privados sob patronato estatal, buscando constituir global players brasileiros. No padrão nacional-desenvolvimentista anterior, iniciado com Getúlio Vargas, investimentos públicos formaram grandes empresas estatais (CSN, Vale do Rio Doce, Petrobras, Eletrobrás, Telebrás). O desenvolvimentismo petista visou fortalecer o grande capital privado. Agora, o Estado, especialmente por meio do BNDES (o maior banco de fomento do mundo), é a principal alavanca para criar gigantes privados, verdadeiras multinacionais brasileiras, para terem capacidade de competir no mercado internacional, reestruturando o capitalismo brasileiro. Luciano Coutinho, então presidente do BNDES, justificava que "empresas brasileiras competentes e competitivas devem merecer o apoio do BNDES para se afirmarem internacionalmente (...), todas as economias desenvolvidas têm empresas transnacionais" (REDAÇÃO, 2009).

Frustrando a expectativa de que Lula refundaria o Brasil, pois representava uma longa caminhada dos movimentos sociais (sindical, popular, pastoral), o maior avanço de seu governo foi juntar uma pitada de política social com a ortodoxia econômica. Apesar disto dar continuidade, em linhas gerais, aos dois mandatos do

${ }^{40}$ Relativo ao Século XIX. 
governo anterior de Fernando Henrique Cardoso ${ }^{41}$, acabou sendo saudado como pós-Consenso de Washington. Nestes anos de governo do PT, esta perspectiva desenvolvimentista (grandes projetos, rodoviarismo, prioridade na aliança com os grandes capitais) seguiu completamente hegemônica e praticamente sem resistências. Lembrando que o BNDES lida com recursos dos trabalhadores, a crítica mais comum questionava a política de escolher os vencedores da economia e subsidiar negócios que geram poucos empregos e elevam a concentração de mercado (bolsa empreiteira).

As cidades pioraram muito e vão piorar mais, não por ausência de planejamento urbano e leis. Inviabilizam-se por um problema estrutural: são construídas para servir ao automóvel, lembrou Ermínia Maricato (2010). Os recentes incentivos para a indústria automotiva (como a desoneração fiscal para compra de automóveis e subsídios para a aquisição de caminhões à diesel - erro duplo: caminhões e diesel) levaram a mais do que dobrar o número de automóveis em circulação entre 2003 e 2014, expandindo significativamente a já ampla frota de caminhões, ampliando a irracionalidade e o caos nas cidades e nas rodovias. Em vez de desenvolver outros modais (ferroviário, aquático ou mesmo tubulações para escoamento de combustível) - mais compatíveis com o imenso litoral e a maior rede hidroviária do mundo - o aprofundamento da custosa e fatal opção rodoviarista vai na contramão do futuro cada vez mais pautado por energias não fósseis e renováveis. Outra trágica sequela do rodoviarismo é ele ser um dos maiores fatores do alto custo Brasil, limitando e empobrecendo nossa economia.

Além da opção pela Copa e Olimpíadas ${ }^{42}$, cabe arrolar também entre os mais emblemáticos feitos do lulismo as devastadoras grandes hidrelétricas na Amazônia (Santo Antonio, Girau, Belo Monte, Teles Pires) - obras que nem a ditadura militar conseguiu implantar - e a controversa e ineficaz transposição do São Francisco, opções que se explicam mais pelas vultuosas propinas e caixa dois, pois, do ponto de vista da eficiência econômica, são projetos duvidosos e polêmicos. A implementação disto tudo ocorreu inclusive usando força policial, atropelando

\footnotetext{
${ }^{41}$ Em verdade e de modo geral, políticas colonialistas também encarnaram todas as estratégias de desenvolvimento tupiniquins buscadas ao longo do Século XX. Aquela disjunção entre o macrossistema político-partidário e o Brasil profundo não se restringe ao PT e ao PSDB, forças que encenam a pseudopolarização (hegemonizados pelos interesses paulistas ou, no máximo, do sudeste urbanoindustrial brasileiro, espelham ambos uma mesma modernidade transplantada do Atlântico Norte) dominante da política nacional no último quarto de século. Este descompasso se estende ao conjunto partidário como um todo, intransparente e anômalo quanto a corresponder às potencialidades democráticas de uma sociedade cada vez mais diversa, conectada e autônoma, buscando mais confiná-la e tutelá-la para poder dela usufruir como um extrator, do que facilitar sua plena prosperidade que flui dos novos metabolismos da cooperação sem mando advindos da mutação tecnológica em curso.

${ }^{42}$ Durante a ditadura, João Havelange, então presidente da Fifa, procurou seu amigo, o presidente João Figueiredo, e propôs realizar a Copa do Mundo no Brasil. Com extrema lucidez, o general Figueiredo lhe respondeu: "Você já viu uma favela no Rio de Janeiro ou uma seca no Nordeste? Acha que eu vou gastar dinheiro com estádio de futebol?” (FIGUEIREDO FILHO, 2014).
} 
amplos movimentos populares (originalmente também constitutivos da base social petista) que resistiam e apontavam alternativas. Particularmente na transposição do São Francisco, a Articulação do Semi-Árido (ASA) liderou uma imensa concertação de entidades que combateu o privilegiamento do uso econômico desta água em detrimento da propaganda oficial que apregoava sua destinação aos mais carentes. A proposta popular buscava também a revitalização do São Francisco, defendia um projeto alternativo de abastecimento de caráter mais difuso e dinamizador de clusters produtivos (redes econômicas locais), atendia uma população quase quatro vezes maior - deveras necessitada - e pela metade do preço da transposição (SUZUKI, 2006; IHU, 2017).

$\mathrm{Na}$ contramão da opção dos governos do PT pelo grande capital ${ }^{43}$, à medida em que o Século XXI avança, consolida-se a irrupção vulcânica da fantástica criatividade que brota da imensa maioria dos outrora condenados da terra. Esta eclosão revela o desabrochar de um Brasil includente, liderado por mulheres, com forte presença negra e intenso protagonismo camponês, indígena e dos pequenos empreendedores. Um Brasil onde Anitas $^{44}$ não mais assujeitadas buscam ganhar "dinheiro e projeção com seus corpos, no comando da própria monetização de suas vidas"(BENTES, 2017). Passo a passo, a carne negra deixa de ser a mais barata no mercado. A natural busca por melhorias vai deixando de ser inibida por relações sociais desfavoráveis e ideologias maniqueias.

Por outro lado, as tecnologias de comunicação eliminam barreiras para que pessoas comuns se posicionem como referências relevantes em determinados setores, gerando uma caótica e explosiva manifestação de diversidade que pulveriza centralismos e comandos hierárquicos. Exemplo disto é o fenômeno dos youtubers (pessoas populares no YouTube) que viralizam e se tornam rápida - e muitas vezes efemeramente - fenômenos de massa.

$\mathrm{Na}$ mesma medida em que as instâncias político/institucionais se encolhem e paralisam, pois se distanciam cada vez mais de cumprir seu papel para a provisão

\footnotetext{
${ }^{43}$ Um conjunto significativo de autores comprometidos com o "poder social" e transformações práticas desde abaixo não se intimida em criticar as insuficiências e contradições não apenas da era petista e sua "hegemonia às avessas", mas também do recente ciclo de governos progressistas na América Latina, entre os quais: Alberto Acosta; Cesar Benjamin; Eduardo Gudynas, Francisco de Oliveira; Gustavo Esteva; Leda Paulani; Maristella Svampa; Raul Zibech, Rui Braga e Ruy Fausto. Destaco em particular as seguintes obras: Cinco mil dias. O Brasil na era do lulismo (Boitempo, 2017); Descolonizar o imaginário (Elefante, 2016); Hegemonia às avessas (Boitempo, 2010); R. Fausto: Caminhos da esquerda (Cia. das Letras, 2017); José S. Martins: Do PT das lutas sociais ao PT do poder (Contexto, 2016); Raquel Rolnik: Guerra dos lugares (Boitempo, 2015); Fábio Santos: Além do PT (Elefante, 2016); M. Svampa: Debates latinoamericanos (Edhsa, 2016); Fábio Zanini: Euforia e fracasso do Brasil grande (Contexto, 2017).

${ }^{44}$ Refiro-me ao maior e mais arrebatador fenômeno pop brasileiro em termos de repercussão mundial, o videoclipe Vai, malandra com o funk feminino da cantora e compositora Anitta (RJ, 1993). Em março de 2018, ela foi uma das vencedoras do iHeartRadio Music Awards, o qual elege os destaques da música nas rádios dos Estados Unidos.
} 
daquilo que é indispensável para a vida comum (saneamento, educação, segurança, mobilidade), a participação da sociedade e suas redes conquista um espaço cada vez maior. Progressivamente vemos $n$ sinais de que frações substantivas do nosso povo, historicamente oprimidas e ignoradas, começam a sair da sua condição de minoridade intelectual, social e política. Aos poucos a Constituição Cidadã de 1988 começa a frutificar, especialmente no que tange ao reconhecimento dos povos indígenas. E a resultante da controversa política de cotas também promete uma grande colheita.

\section{Etnogênese: a reversão do processo colonial}

"A identidade de um povo não deve buscar-se na originalidade de seus traços culturais, mas na capacidade deste povo de gerar sentidos sociais e políticos que o unificam na luta por definir sua razão de ser como povo"

(Carlos Zambrano).

"Quando se trata dos europeus, chamamos este processo de Renascimento. Quando se trata dos outros, chamamos de invenção da tradição, um signo de decadência cultural que produz apenas simulacros de um passado morto"

(Marshall Sahlins).

"Querer apegar-se à tradição ou reatualizar as tradições abandonadas é ir não somente contra a história, mas contra seu próprio povo"

(Fanon).

Aquela premiação de uma construção inspirada nas técnicas indígenas (tópico 6) é reveladora do quanto ainda temos por descobrir e reconhecer quanto à positividade da contribuição das sociedades primitivas. Pois, no dizer de Pierre Clastres (1978, p. 139), elas "não são embriões retardatários das sociedades ulteriores [...] não se encontram no ponto de partida de uma lógica histórica que conduz diretamente ao termo inscrito de antemão".

Esta ruptura com o tempo linear e seu decorrente evolucionismo foi antecipada por Oswald de Andrade. Há quase um século ele quebrou com o espelho europeu e subverteu, com sua antropofagia, a imagem do primitivo como inferior, partindo do pressuposto de que "a alegria é a prova dos nove". Contribuiu para revelar uma sociedade caraíba "sem complexos, sem loucura, sem prostituições e sem penitenciárias" (1990, p. 51-52).

Apesar de Oswald e Clastres, o processo de descolonização muito tardou e somente no Século XXI começa a decolar com mais vigor, agora pelo próprio protagonismo indígena e popular, enfrentando grandes resistências e fortes preconceitos. Paulatinamente, os povos nativos, ressurgidos, vão rompendo a teia 
colonial europeia que os envolveu e degradou como inferiores e subalternos, desnudando a armadilha da ilusão de primitivismo que os encobre, pois demonstram que a sua presença não significa "empecilho para o progresso. No dizer de Manuela Carneiro da Cunha (1992, p. 22),

\begin{abstract}
durante quase cinco séculos, os índios foram pensados como seres efêmeros, em transição: transição para a cristandade, a civilização, a assimilação, o desaparecimento. Hoje se sabe que as sociedades indígenas são parte de nosso futuro e não só de nosso passado.
\end{abstract}

Manuela captou isto na aurora do movimento indígena contemporâneo (que irrompe no final dos anos 1970). Todavia, Darcy Ribeiro, em que pese seu hercúleo esforço em salvar os remanescentes indígenas, literalmente, por estar visceralmente agarrado à tese da mestiçagem, não entendeu o significado dos povos silvícolas para a civilização brasileira e não acompanhou Manuela neste diagnóstico. No que tange à temática indígena, Darcy foi ultrapassado pelos fatos, ou seja, pelo levante indígena hodierno. A seguinte percepção de De Castro bem desvela os limites darcisistas: "Nas últimas décadas têm acontecido no Brasil algo inverso ao problema que ocupava os fundadores da sociologia do contato. Em vez de os índios se tornarem, aos poucos, brasileiros, são os brasileiros que estão virando índios." (CARIELLO, 2013).

Uma “cegueira ontológica” (BARTOLOMÉ, 2006, p. 201) cristalizada em conceitos estatísticos e censos demográficos gerou um etnocídio estatístico (BATALLA, 1981, p. 21) que invisibilizou e subestimou tanto o indígena quanto o rural. A ficção oficial superdimensionou o urbano, classificando como cidades todas as sedes municipais: até tribos indígenas são consideradas centros urbanos, alertou José Eli da Veiga (2002). O processo colonial etnocida levou as identidades indígenas e camponesas a sobreporem-se por longo tempo - configurando populações "campesíndias”, vislumbrou Armando Bartra (2008, p. 181).

Aos poucos, um processo reverso leva a reemergir grupos étnicos que se identificam como originários (fenômeno denominado de etnogênese), bem como um revigoramento do campesinato conjugado com dinâmicas de recampesinação vide a consolidação das cada vez mais vigorosas redes de agroecologia (tópico 4$)^{45}$. Isto é surpreendente e aparentemente anacrônico, pois vai na contracorrente da ainda hegemônica visão urbanista e industrializante que conduz o projeto nacional.

\footnotetext{
45 Para um aprofundamento sobre os processos de recampesinação, consultar as obras de Eric Sabourin, Jan van der Ploeg, Dominique Temple, Manuel Toledo, Joan Martínez Alier, Maria Ignez Paulilo, Marilda Menezes, Sérgio Schneider, Armando Bartra e Ricardo Abramovay. Para a compreensão da etnogênese contemporânea os já citados Bonfil Batalla, Bartolomé, De Castro e Carneiro da Cunha são centrais.
} 
Talvez, sejam sinais de uma profunda transição civilizatória, como já indiquei em outro lugar ${ }^{46}$. As facilidades comunicacionais advindas das novas formas tecnológicas diluem o clássico antagonismo rural-urbano característico da modernidade eurocentrada, difundindo dinâmicas rurbanas e pós-tradicionais que não mais opõem o rural ao urbano, mas combinam fortemente seus elementos, permitindo sermos rurais na cidade e urbanos no campo (CARNEIRO, 1998), tal como na profecia das cidades-jardins de Ebenezer Howard ${ }^{47}$. A reaproximação das cidades com o rural e o indígena, uma vez que estes deixem de ser despossuídos, poderá reverter e sanar o atual cenário colonial-metropolitano de medo e violência entre a crescente, envolvente e segregada periferia e os centros urbanos, degradador de qualquer perspectiva de urbanidade e civilidade.

A dispersão produtiva global no mundo das redes, e a profusão de inovação que dele jorra, que ultrapassa qualquer tentativa de enquadramento e controle (as quais simplesmente a castram). Conjugada com o advento da perspectiva ecológica da vida e o reconhecimento de que adentramos no antropoceno, desencantou o modelo fáustico de desenvolvimento e desvelou sua magia do progresso posta como corrida cega e confrontativa para o futuro. Não é suficiente que iluminados

\footnotetext{
46 "Os campesíndios, aproximadamente a maioria da humanidade, estão fora do lugar dentro da sociedade moderna, a qual gerou uma enferma assimetria campo-cidade, em detrimento do campo outra ferida que retrata a colonialidade gerada pela epistemologia-ontologia moderna. Por assumir um papel protagônico dentro das novas formas de economia ecológica, por aportarem elementos valiosos na construção de uma economia para a vida, a iletrada comunidade campesíndia está a desafiar epistemológica, política e economicamente a hegemonia do sujeito moderno (solipsimista, urbano, branco, masculino e escolarizado). Do mundo camponês e sua multifuncionalidade desponta - com a agricultura familiar, agricultura orgânica e agroecológica, permacultura, reservas extrativistas, bambuzerias, e a reabilitação do conhecimento farmacológico tradicional - uma recuperação epistemológica de ontologias não ocidentais, outras formas de valorar, de se relacionar com a natureza, outras dinâmicas de poder" (LISBOA, 2014, p. 76).
}

47 Sua obra "Cidades-jardins de amanhã" (HOWARD, 2002) demonstrou que "não há somente duas alternativas, vida urbana ou rural. Existe uma terceira que assegura a combinação perfeita de todas as vantagens da mais intensa e ativa vida urbana, com toda beleza e prazeres do campo" (p. 108). Tomando emprestado do socialismo sua concepção do esforço comum, e do liberalismo a preservação do autorespeito e confiança em si mesmo, Howard elaborou um modelo que, "embora encoraje a iniciativa individual, permite a mais completa cooperação" (p. 117). Ao desenhar cidades-jardins, enfatizando a interpenetração entre campo e cidade, Howard foi o grande impulsionador das alternativas urbanas experimentadas no Século XX (na cidade de São Paulo, por exemplo, a região de maior área verde, os "Jardins" - Jardim América, Pacaembu, Morumbi... - origina-se de projetos urbanísticos do início do Século XX inspirados diretamente em Howard). Howard foi precursor dos atuais movimentos de Reforma Urbana, Ecovilas, e Slow Cities.

Todavia, a proposta da cidade-jardim foi por muito tempo esquecida, predominando o ideário modernista à la Corbusier, ou seja, a crença na racionalização do concreto e do automóvel divorciada dos aspectos socioambientais. As ideias de Howard foram esmagadas pela ação de duas febres que se viviam no alvorecer do Século XX: a ideológica e a tecnológica. De um lado, a polarização ideológica entre comunistas e capitalistas, de outro, o encanto gerado pelo advento do automóvel e do elevador movido à eletricidade, impactando decisivamente a vida urbana, levando à verticalização das cidades e ao privilegiamento do transporte motorizado individual como forma de locomoção. 
acessem os fundos públicos e detenham o mapa da mina para que este país vá para frente sem culpa e sem pecado, mesmo estando abaixo do Equador.

\section{Devir Brasil: ultrapassando os projetos cupulistas de nação}

"Um povo se define pelo que quer vir a ser"

(Cesar Benjamin).

"Os processos são os devires, e estes não se julgam pelo resultado que os findaria, mas pela qualidade de seus cursos e pela potência de sua continuação"

(Deleuze).

Este novo mundo reticular torna ainda mais verídica tanto as proclamações de José Mariátegui, Homi Bhabha, Benedict Anderson e Ernest Renan de que nação é alegoria, narração, invenção, comunidade imaginada, plebiscito diário, quanto à denúncia de Samuel Johnson do apelo ao patriotismo ser "o último refúgio do canalha". O nacionalismo, ideologia que faz do "pertencimento a uma abstração coletivista - a nação - o valor supremo e a principal credencial de um indivíduo" VARGAS, 2010: 231), é um imaginário útil às forças que se locupletam com o aparato do Estado, mas possui um caráter xenófobo e regressivo, pois impede aos povos perceberem os interesses comuns a toda humanidade e apenas amplia o fosso entre os mesmos, sem compreender que a própria identidade é um jogo de contrastes.

Por contraste, uma afirmação profética de Alceu Amoroso Lima, proferida em 1917, ajuda a compreender a grandeza das novidades em curso. Para Alceu, no Brasil "o Século XVI pertenceu a Pernambuco, o XVII à Bahia, o XVIII a Minas Gerais, o XIX ao Rio de Janeiro, o Século XX é o século de São Paulo" (apud GONÇALVES, 2012, p. 176). Cem anos após, é difícil descortinar alguma hegemonia regional vigente neste novo milênio, e, sinceramente, não espero que o Sul, Brasília ou algum outro lócus a obtenha. Isto seria um grande desastre e um aprofundamento da secular sangria deste país a níveis insuportáveis. A aposta é que no Século XXI não haverá mais centralidades (espacial/política) ou demiurgos salvadores, que o Século XXI não será o da hegemonia de alguma vertente/região, mas da consagração do afloramento das diversidades compósitas do Brasil profundo.

A busca pela homogeneidade nacional sufoca as diferenças, excluindo a vital alteridade componente e definidora de qualquer perspectiva identitária. Hipostasiar ou fetichizar uma cultura, absolutizando-a e invocando uma pureza originária que nunca existiu é catastrófico, pois gera incompreensões, obtusidades e barbarismos. O ser humano e os povos não se fundam somente no acervo de seu passado - senão as tradições ficariam mumificadas e intocadas -, mas está em 
processo de permanentes intercâmbios e construção. Como seres orientados para o futuro, não estamos prisioneiros do passado, ainda que ele viva em nós, como canta Paulinho da Viola. "Se o homem é projeto, como diz Sartre, é o futuro que comanda as ações do presente", sentencia Milton Santos (1999, p. 265).

A afirmação identitária, especialmente quando negadora da pluralidade mutante que somos, ou seja, quando feita de forma monolítica, metafísica e estereotipada, carrega armadilhas e problemas, podendo dificultar, travar ou mesmo negar o elemento mais profundo do processo de descolonização: restaurar/reabilitar o humano. As próprias tradições histórico-culturais são inventadas e reinventadas permanentemente. Fixar-se em uma tradição é cair na armadilha etnofilosófica que essencializa a mesma, é amarrar nossos pés, mãos e pensamento, e nos deixar escravizar a deuses inimigos da liberdade impostos por nós mesmos.

Por um tempo demasiado, recorrentemente fomos possuídos pela ânsia da procura de uma "identidade brasileira", pela ideia da formação nacional em construção e que algum dia se completará. Ora, esclarece Paulo Arantes (1997, p. 12), este conceito de nacional é uma noção normativa que corresponde a um ideal europen de civilização. Com a chegada simultânea dos novos metabolismos econômico-planetários e da perspectiva pluriversal de existir - a aceitação das inúmeras formas e experiências de humanidade, a existência de modos diferenciados de ser - "não mudou apenas o caminho. Mudou a pedra". Ou seja, conforme enfatizará Marcos Nobre (2012), já não é mais da 'formação da nação', com sua unidade e homogeneidade, que se trata", pois o "processo de 'formação' se encerrou - ainda que não tenha se completado.

Fixado na construção da nacionalidade, hoje o paradigma da formação está obsoleto e cumpre uma função primordialmente ideológica - e retrógrada (NOBRE, 2012). Assim, cabe deixar para trás a obsessão da formação do Brasil e assumir a ideia de um permanente devir, sempre incompleto e aberto ao mundo.

Todavia, a recusa do nacionalismo jacobino, provinciano e confinador não significa diluir-se e dissolver-se num cosmopolitismo estandartizador, devendo ser acompanhada pela afirmação de um nacional não nacionalista. Cada povo precisa de marcos de referência, vínculos e campos de sentido, para que seus membros possam comunicar-se entre si, bem como para ser reconhecido e dialogar com os demais povos sem ser subjugado e espoliado. O alerta, aqui, é para quão traiçoeira é a questão identitária. A busca por descobrir, revelar e afirmar uma particular identidade é problemática, enganosa e destrutiva quando feita narcisisticamente e deixa de gravitar em torno do reconhecimento do outro como elemento da mesma, sem o qual exacerbam-se medos e intolerâncias.

Esta “dialética do localismo e do cosmopolitismo" é, segundo Antonio Candido (1967, p. 129), "a lei de evolução da nossa vida espiritual”, e foi assim expressa nos anos 1920 tanto por Mário de Andrade - "todo e qualquer alastramento do conceito de pátria que não abranja a humanidade inteira me parece odioso" (apud 
PERRONE-MOISÉS, 2007, p. 72) - quanto por Mariátegui - “dentro de nossas fronteiras acampa a humanidade” (1991, p. 367). Mais recentemente, também Aimé Césaire expôs uma posição adequada sobre esta antinomia particularuniversal:

Há dois modos de perder-se: por segregação muralhada no particular, ou por dissolução no "universal". [...] Minha concepção de universal é a de um universal depositário da profundização e coexistência de todos os particulares [...]. Universal, sim, porém faz já muito que Hegel nos mostrou o caminho: o universal, porém não por negação, mas como aprofundamento de nossa própria singularidade (apud BIDASECA, 2010, p. 69).

Hoje, esclarece Nobre (2012), o vínculo tradicional entre 'centro' e 'periferia' mudou de caráter, uma vez que a subordinação internacional já não segue o padrão inter-nacional nem se organiza em termos de nações, países ou Estados. De forma mais rápida e profunda que a revolução industrial, a revolução digital está a mudar os modos de vida e produção, potencializando um outro padrão de desenvolvimento, diferenciado do dominante fundado na coercitiva extração de excedente social. Agora brotam formas descentralizadas de acumulação baseadas na inovação permanente advinda da interatividade exponencial e do consequente ressurgimento dos commons. $\mathrm{O}$ modo ocidental expansivo e expropriativo de desenvolver as forças produtivas vai se esgotando. $\mathrm{Na}$ dinâmica societária contemporânea, conforme avaliam Antonio Negri e Giuseppe Cocco (2005, p. 34):

A transformação da dependência em interdependência coloca em evidência a nova situação: o mercado mundial não tem mais um lado de fora e os conflitos o atravessam em todos os seus níveis: entre o centro e a periferia, é certo, mas também no centro e na periferia. É esta a mudança que destroça qualquer perspectiva de construção de um projeto nacional-desenvolvimentista ou nacional popular (ou ainda nacional-democrático). A perspectiva do desenvolvimento perde seu horizonte nacional e, portanto, seus ilusórios atalhos tecnocráticosautoritários.

Também do ponto de vista do perspectivismo, a antinomia centro e periferia é uma metáfora que já não tem mais valia, uma vez que a dinâmica global não amuralha e imobiliza os grupos humanos. Contudo, se nas redes os centros carecem de importância fulcral, o policentrismo multiescalar admite múltiplos centros: há centros nas periferias e periferias nos centros. Efetivamente, não há uma homogeneidade e indiferenciação espacial no conjunto da sociedade. A ausência de um centro absoluto e definidor, regente de todo universo, não implica 
que qualquer lugar seja o mesmo e que tudo seja plano, como defendeu Thomas Friedman (2005). Existem fluxos e pontos de intersecção que geram campos de força e se convertem em centros ad hoc que se projetam e conformam realidades, ainda que sem configurar uma integradora totalidade.

Mas, outra metáfora, agora de De Castro (2015, p. 21), é perfeita para delinear a grande transformação em andamento: nosso povo está a despertar de um coma étnico, pois tanto aos poucos nos livramos dos paradigmas eurocêntricos (inclusive o marxismo, entendido este como ideologia ou doutrina) quanto vamos (re)descobrindo particularidades daquilo que somos e que até então não percebíamos e não conhecíamos, ou, mesmo, não entendíamos.

As revoluções nacionais na América Latina (especialmente a brasileira), que fizeram a independência e ergueram nossos Estados-Nação no início do Século XIX, não foram advindas das maiorias populares afro-ameríndias, mas das brancas elites crioulas, as quais então viviam assustadas com o fantasma do ocorrido em Santo Domingo (Haiti). É este o grupo social gerador da nação escolhida, cujas características configurarão a essência nacional, uma vez que nacionalismo significa a imposição de uma alta cultura em uma sociedade onde predominavam baixas culturas na maioria, se não na totalidade, da população. Significa a difusão de um idioma (...) (Gellner, apud BRESSER, 2008). Assim, elas mantiveram as maiorias (que configuram outras inúmeras nações) tão estigmatizadas, violentadas e subjugadas quanto nos mais de três séculos de escravidão. Ou seja, a condição colonial, para a grande parte do povo, não se alterou. Sem uma efetiva descolonização, do imaginário social e das instituições e estruturas de poder, é inviável um genuíno exercício autônomo do poder nacional. Portanto, a primeira descolonização, ocorrida com a independência política dos novos estados nacionais latino-americanos representou apenas uma "rearticulação da colonialidade de poder sobre novas bases institucionais” (QUIJANO, 2000, p. 236).

No caso brasileiro, são ainda mais acentuadas as linhas de continuidade entre nosso estado nacional e o passado colonial, face à nossa independência ter sido feita pelo próprio rei de Portugal, ou face à manutenção tanto da escravidão e da monarquia ao longo de quase sete décadas após a mesma quanto da nossa própria integridade territorial (ao contrário do domínio espanhol). Os patrimônios das antigas oligarquias ficaram intocados, inclusive após a abolição. A proclamação da República em nada alterou o silenciamento do povo (que, aliás, se reagiu foi para defender o imperador), apenas renovou o olhar colonizador brasílico, agora impulsionado com o emblema ordem e progresso, do qual o contemporâneo desenvolvimentismo dá continuidade. A primeira política educacional brasileira (e a primeira universidade) apenas surge na década de 1930.

O ressurgimento da indianidade, a emergência e vigor da negritude, o revigoramento do campesinato (com as redes de agroecologia e de agricultura familiar) e uma consolidada despatriacarlização (emancipação feminina e de 
gênero) indicam o fim da branquidão, do domínio masculino e paulista (industrial) do projeto nacional, sendo expressões da avassaladora fermentação social em curso no Brasil. Ao se cozinhar tudo isto no caldeirão de uma inserção cada vez mais globalizada de seus principais atores, teremos um profundo desmontar das perigosas e turbulentas armadilhas identitárias postas pela ideia de pureza de um nacional uno, originário, imutável e essencial, ao qual se deve uma lealdade incondicional. Assim, revelar-se-á o verdadeiro caráter do apelo retórico por sacrifícios em nome da nação e seu desenvolvimento: um disfarce para a manutenção dos privilégios e da velha subalternidade colonial sobre as maiorias.

Estas fermentações equivalem a uma segunda descolonização, pois desafiam o padrão colonial de poder vigente na América Latina, retirando da invisibilidade populações excluídas classificadas como inferiores. Os que estão no polo de miséria do capitalismo (re)conquistam, com esforços individuais ou pela organização comunitária de seu trabalho, o acesso a bens e serviços, num autêntico processo de emancipação e democratização, redefinindo e ampliando, com suas cores, línguas e técnicas, a sociedade vigente e seu modelo europeu de Estado-nação uno e hegemônico.

\section{Superando o não-ser: a busca por uma vida melhor}

“O esforço natural de cada indivíduo para melhorar sua própria condição, quando se permite que ele atue com liberdade e segurança, constitui um princípio tão potente que, por si só, e sem qualquer outra ajuda, não somente é capaz de levar a sociedade à riqueza e à prosperidade, como também de superar uma centena de obstáculos impertinentes com os quais a insensatez das leis humanas com excessiva frequência obstrui seu exercício"

(Adam Smith).

"Desenvolvimento é um processo de expansão das liberdades reais que as pessoas desfrutam, é a expansão das suas capacidades"

(Amartya Sen).

“As pessoas não estão sempre iguais, ainda não foram terminadas. Elas vão sempre mudando. Afinam ou desafinam"

(Guimarães Rosa).

Acentuar a importância dos esforços autonômicos das periferias emergentes não significa defender que apenas delas advenham positividades ou negar que das mesmas também brotem elementos sórdidos e regressivos. Incide-se num distorcido hipostasiamento da periferia quando apresentada meramente como vítima isenta de ambiguidades e responsabilidades. É maniqueísmo vulgar acreditar que os pobres tanto são seres ultra-humanos que redimirão o mundo oprimido por um maléfico Ocidente, quanto estereotipá-los como impotentes, parasitas e 
perigosos, conforme os estigmatizou o mito da marginalidade (PERLMAN, 1977). A resiliência dos pobres e seu empreendedorismo, todavia, não é suficiente para configurar uma estratégia de desenvolvimento, pois o contínuo aperfeiçoamento humano destes (e de todos) exige acessar tecnologias modernas e incluí-los na torrente de inovação que delas brota, o que passa por regimes de comércio e intercâmbio internacional. $\mathrm{O}$ ponto central defendido neste artigo não é trazer modelos de desenvolvimento inclusivo (SACHS, 2008) que prescindem das perversas dinâmicas de acumulação primitiva, mas ponderar ontológica e politicamente se aquelas iniciativas de empowerment revelam a ascensão à maioridade de grupos representativos dos setores majoritários da população, os quais assim ascendem e deixam de ser tutelados.

Por muito tempo, procurou-se nos damnés de la terre e circuitos econômicos populares (Milton Santos) embriões de outros modos de produção, de uma outra economia, alternativa, depositando no mundo dos pobres as esperanças revolucionárias da humanidade. Parece um despropósito sobrecarregar com tais expectativas os setores populares, mas é o que proclamam frações eminentes da teoria social contemporânea, seja de corte anticapitalista - representam o começo da "construção de um modo de produção alternativo ao capitalismo" (SINGER, 2002, p. 127) - seja ultraliberal: perfazem uma "nova classe empresarial" que "constitui o capital humano indispensável para o arranque econômico" (DE SOTO, 1987, p. 326).

Em grande parte, estas perspectivas estão prisioneiras duma visão dualista, como se existissem dois mundos e duas economias radicalmente distintas e antípodas uma envolta por relações morais que primam pelo respeito ao comum e a outra regida apenas pelo imperativo da maximização utilitarista e solipsimista ${ }^{48}-$ e fosse admissível buscar um outro desenvolvimento ao lado do moderno. Como já ressaltado na reflexão de Cocco atrás citada, a ideia de existir um lado de fora, puro, é uma fantasia distópica que só nos empurra para becos sem saída e acarreta impasses insolúveis.

Em primeiro lugar, esta ótica é hipócrita, neocolonial e multiplicadora de ressentimentos, pois condena os menos desenvolvidos a um desenvolvimento de segunda mão, a "comer insetos" (como recomendou a FAO em tempos recentes), deixando o caviar com os europeus, uma vez que ninguém vai colocar o guizo nos

\footnotetext{
48 Para viver, o ser humano carece de propósitos e condições materiais, significados e instrumentos, sonhos e cálculos. Dois imperativos coexistem e são complementares: o simbólico/comunicativo e o econômico/biológico. Manejá-los é imprescindível e define a sociedade boa e próspera. Nossa sanidade/sobrevivência impõe ter os pés na terra e orientarmo-nos pelas estrelas. É patético e trágico apartar e isolar estas dimensões constitutivas do humano. Cada vez que o tencionamento entre elas resulta no domínio de uma e esvaziamento da outra, a vida empobrece e se reduz. As piores atrocidades surgiram de regimes que radicalizam uma destas vertentes, a instrumental/analítica ou a ético/dialética: o racismo científico dos nazistas e o materialismo dialético dos soviéticos.
} 
mais ricos: afinal, como estes se reformarão? É saudável e gerador de robustas eficiências reivindicar e partir de formas de desenvolvimento local. Todavia, se este for definido como isolar-se em guetos territoriais e separar-se do sistema global ${ }^{49}$, apenas engendrar-se-ão jeitos ainda mais brutais de dominação e pobreza, advertem Negri e Hardt (2001, p. 305) - vide caso da Coréia do Norte. Como também é irrealista desqualificar a agenda ambiental e a busca não mimética de sociedades saudáveis e suas tecnologias apropriadas, pois não é mais possível acreditar num ilusório crescimento sem fim da cornucópia industrial moderna transbordando e beneficiando a todos, urge tratar de forma global, não dicotômica e não economicista a problemática do desenvolvimento ${ }^{50}$.

Por outro lado, este prisma distorce e encobre o real sentido das dinâmicas populares, seja exacerbando-as, como visto acima, seja despotencializando-as, o que gera incompreensões e frustrações, como as expressas por Quijano (1998, p. 142): elas parecem "muito pouco, demasiado pouco, para fundar um modo de existência social estável e diferenciado, uma 'economia alternativa' ao capital”. Em outro balanço (2002, p. 488) reitera ainda que a quase totalidade delas "não pode ir mais longe do que meras "estratégias de sobrevivência".

Os termos do que transcorre no campo econômico popular foram melhor lançados por Hirschman em sua avaliação das grassroots: a aventura do desenvolvimento popular é "valiosa em si mesma" (1986, p. 110), mas não pelo seu significado macroeconômico. Seu valor reside no que ela representa de mudança nas microrrelações sociais e decorrente melhoria concreta da condição das pessoas. A ênfase jacobina na macroescala ignora que "não podemos transformar o mundo se, ao mesmo tempo, não nos transformarmos a nós mesmos", anteviu lucidamente Heller (1985, p. 117) ${ }^{51}$.

${ }^{49}$ Como, por exemplo, defende Samir Amin (1986) com a tese da desconexão com o mercado mundial.

50 Mesmo com estas precauções, tampouco cabe se fixar na linguagem desenvolvimentista com seus modelos e fórmulas, inclusive as contra-hegemônicas. A mesma é insuficiente, inadequada e perigosa tanto para qualificar e enquadrar o imponderável impulso vital de aperfeiçoamento e expansão das possibilidades humanas na eterna busca de afluência e uma indefinível vida melhor, quanto para elucidar as possibilidades presentes para uma humanidade cada vez mais enredada. Caso contrário, requentaremos os idílicos apelos terceiro-mundistas por uma Nova Ordem Econômica Internacional. Após algumas décadas, seus poucos efeitos práticos positivos levaram ao esquecimento e abandono daquela retórica.

51 Isto também foi belamente expresso na música Até quando? (de Gabriel Pensador, Tiago Mocotó e Itaal Shur): "muda, que quando a gente muda, o mundo muda com a gente. A gente muda o mundo na mudança da mente. E quando a mente muda a gente anda pra frente. "O ser social sempre foi uma combinação de liberdade e determinismo. Mas, o impulso de inovação imanente aos novos metabolismos societários amplifica a importância da perspectiva ontológica, permitindo superar a obsessão com as "macroestruturas" e suas "leis objetivas" que subestimaram e excluíram a subjetividade humana (MÉSZÁROS, 2002, p.933), impedindo de ver o óbvio: a história é produto da ação humana, sem fatalismos nem plena autonomia pois, como vislumbrou Tawney $(1971,260)$, ela "é um palco onde forças que estão sob controle humano lutam e cooperam com forças que não estão”. 
Ora, se "a dominação não se origina na exploração e remete sobretudo ao controle da autoridade e da subjetividade", reconhece Quijano (2002, p. 509), então cabe valorizar enfaticamente as mudanças na estrutura da subjetividade decorrentes da produção e reprodução autônoma da própria vida. É absolutamente central e imprescindível para uma verdadeira emancipação romper com as formas transcendentais do político - orientadas por vetores exógenos (de fora para dentro) e autoritários (de cima para baixo) - que engendram despersonalização, dependência e dominação.

A superação do não-ser colonial é um processo ontológico de renovação do ser. As experiências trazidas na primeira parte deste artigo indicam que as lutas e os esforços dos excluídos por gerar seu sustento econômico e melhorar sua vida representam mais que um ato de resistência e sobrevivência: abrem perspectivas existenciais, resgatam dignidade, autoestima e confiança. A autoconstrução da vida é geradora de um poder constituinte (Negri e Hardt; Alberoni), mobiliza recursos ocultos e sinérgicos (Max-Neef) e produz uma força expansiva, criativa e desmedida, livre e imprevisível, permitindo às pessoas comuns ativar suas potências, transcender as circunstâncias (Unger) e romper com qualquer cativeiro.

Mas não há humanização sem outridade, como proclamam enfaticamente seja a filosofia africana do Ubuntu - Umuntu ngumuntu ngabantu (uma pessoa é uma pessoa através de outras pessoas, provérbio Zulu) - seja a descoberta do inconsciente pela psicologia moderna. As pessoas são como palavras, só têm sentido se junto das outras, canta Emicida. Isto é: a alteridade é constitutiva do humano, o outro me constitui, para ser eu careço do outro. Parodiando Simone de Beauvoir, o ser humano não nasce ser humano, ele torna-se gente ao longo de sua vida, e condição sine-qua-non para tal é a dimensão de alteridade.

Uma pretensa diferença ontológica entre colonizador e colonizado é o elemento central e gerador da condição colonial, desumanizando e embrutecendo a ambos. Quando cotidiana e metafisicamente o outro é negado, quando o reduzo ao mesmo e obstinadamente não reconheço a sua humanidade, descartando-o na vala do não-ser, uma estranheza radical (a recusa da alteridade) dá lugar e comanda degenerativamente a política e a sociedade, de modo que a alteridade original e constitutiva da vida transfigura-se numa forma absolutamente antagônica e mortal, atrofiando e mutilando a condição humana tanto de quem é espoliado quanto do espoliador. A tomada do poder, esclareceu Fanon, não é condição suficiente para definir uma transformação autêntica e profunda, a qual gravita na órbita do ser: são mudanças concretas na vida (e de vida) das pessoas comuns (e não propostas abstratas e gerais) que desfazem o mundo do não-ser, restabelecendo a humanidade dos subalternizados e, por tabela, também dos espoliadores.

Se ser bumano é estar num permanente processo de humanização, mudar a vida de modo a libertar-se da coisificação e das carências de sua condição social, especialmente quando se desfaz a linha divisória entre aqueles que são e os que não- 
são, perfaz uma mutação ontológica mais profunda e verdadeira que os golpes de Estado e a tomada do poder, que em geral não revolucionam nada, a não ser os dirigentes que nele se instalam. E, como naqueles esforços inclusivos também prima uma postura biocêntrica de conexão interativa com a natureza (de reverência à Pachamama, pois dela participamos: somos a Terra), trata-se, portanto, de um giro ontológico, uma autêntica mudança tectônica onde uma ontologia relacional (ESCOBAR, 2014) desloca e ultrapassa o império da cosmovisão antropocêntrica e ocidental de corte dualista e reducionista.

À luz da luta de Frantz Fanon pela libertação da colonialidade, do reconhecimento da outridade de Tzvetan Todorov e da ótica pluriversal de Arturo Escobar, afirmo que as lutas pela dignidade e os esforços autonômicos e includentes são lutas e processos ontológicos, pois visam, em primeiro lugar, a superação da colonial condição de não-ser e o restabelecimento da plena humanidade.

Particularmente, antevejo que o Brasil cada vez mais romperá com sua condição decolonial (se completando a emancipação do povão: índios/negros/mulheres/camponeses) e, assim, será inserido criativamente na vida global. Após os ciclos romântico e modernista dos séculos XIX e XX, surgem as condições para romper com as armadilhas iluministas e idealizadoras, que se fixavam na exaltação de elementos exóticos, folclóricos e demiúrgicos, seja na sua forma pura ou na sua assimilação e fusão, com vistas a adentrarmos dependentemente numa forçosa modernidade com base em quiméricas almas nacionais e em clichês patrióticos e grandiloquentes.

\section{Considerações finais}

“A ideia de 'meio ambiente' pressupõe que nós, humanos, estamos no centro e as coisas moram à nossa volta. Na realidade, as coisas não nos rodeiam, nós formamos com elas um mesmo mundo, somos coisas e gente habitando um invisível corpo"

(Mia Couto).

O Brasil do Século XXI, portanto, paulatinamente descortina-se de forma inclusiva (rompendo claramente com a subalternização da sua "ralé"), aberto para o mercado, democratizando-o ${ }^{52}$ e inserindo-se internacionalmente. Ouso afirmar

\footnotetext{
52 Não se trata de apologia ao laissez faire, pois Mercado e Capitalismo se distinguem, havendo entre eles nuances decisivas, além de caber compreendê-los dinamicamente, como processo. Por sua vez, estas categorias são polissêmicas, irredutíveis a uma única e simples apreensão. Ou seja, existem diversos capitalismos e diferentes mercados. Mas, de modo geral, os capitalismos, ainda que vivam no mercado e do mercado, configuram-se como o reino do contramercado, isto é, dos mais fortes. Já mercados,
} 
que, pela primeira vez, o Brasil como um todo, ou melhor, o arco-íris do povo brasileiro, diverso e plural, está prestes a se emancipar dos projetos cupulistas de nação. Estes projetos, como é sabido, mais resultam de disputas e conflitos entre os interesses econômicos das elites que controlam o Estado, do que expressam as vontades populares.

Enfim, o planeta fome desperta, literalmente, do sonho colonial (FANON, 1968, p. 109). Talvez não exatamente como desejado pelos genéricos e unificados anseios da longa tradição brasileira de pensamento crítico de esquerda (Caio Prado, Florestan, Gorender, Ianni etc.) ou seja, com perfil socialista, estatista e igualitário. Aqueles emergentes e batalhadores configuram um Brasil que anseia por dignidade e inserção no mundo do consumo e assim obter uma vida maior, sem apequenamento, que busca vencer com suas próprias forças e mérito e não amparado pelo Estado. Sem padrinhos. Eles conformam um Brasil novo, mais criativo e aberto às possibilidades libertadoras do gênero humano, com maior integração: por nele ressoar uma raiz comunitária (seja a das favelas, seja a dos camponeses, dos povos indígenas e quilombolas), está impulsionado por um metabolismo econômico possuidor de caráter mais responsável e respeitoso da natureza e do ser humano, gerador de dinâmicas de desenvolvimento territorial decoloniais e restabelecedoras da vida.

\section{REFERÊNCIAS}

$\begin{array}{lccccr}\text { ABRATECOM } & \text { ASSOCIAÇÃO } & \text { BRASILEIRA } & \text { DE } & \text { TERAPIA } \\ \text { COMUNITÁRIA. } & \text { Quem somos. } & \text { s. d. } & \text { d. } & \text { Disponível } & \text { em: } \\ \text { http://www.abratecom.org.br/QuemSomos/Abratecom/. } & & & \end{array}$

ACOLHIDA NA COLÔNIA. Website. s. d. Disponível em: $<$ http://acolhida.com.br/>.

AGÊNCIA POPULAR SOLANO TRINDADE. Quem somos. s. d. Disponível em: <https://agenciasolanotrindade.wordpress.com/quem-somos/>.

historicamente, tiveram um papel civilizador. A questão não é mais ou menos mercado, mas qual (ou quais) mercado? Os negócios inclusivos talvez sejam o segredo do almejado "desenvolvimento inclusivo" ou do cobiçado "socialismo democrático": permitem caminhar pelo fio da navalha (onde derrapou a socialdemocracia) posto ao adentrar na economia de mercado, sem se tragar pelo vértice da sociedade de mercado. Em Stuart Mill, K. Polanyi, F. Braudel, Guerreiro Ramos, A. Hirschman, I. Sachs, Mangabeira Unger, L. Dowbor, S. Bowles, A. Sen e S. Zamagni encontramos uma compreensão apurada e superadora da infantil e fundamentalista antinomia mercadofilia versus mercadofobia, bem como em Lisboa (2003). 
AGRECO - ASSOCIAÇÃO DOS AGRICULTORES ECOLÓGICOS DAS ENCOSTAS DA SERRA GERAL. Website. Disponível em: $<$ http://www.agreco.com.br/>.

ALBERONI, Francesco. Gênese. Rio de Janeiro: Rocco, 1991.

AMIN, Samir. La déconnexion. Paris: La Découverte, 1986.

ARANTES, Paulo. Providências de um crítico literário na periferia do capitalismo. In: ARANTES, Paulo; ARANTES, Otília. Sentido da formação. São Paulo: Paz e Terra, 1997.

ARCOVERDE, Letícia. Recrutadoras especializadas em inclusão racial ganham espaço entre múltis. Valor Econômico, 2017. Disponível em: $<$ https://www.valor.com.br/carreira/5016362/recrutadoras-especializadas-eminclusao-racial-ganham-espaco-entre-multis $>$.

ARTE BANIWA. Website. Disponível em: <https://www.artebaniwa.org.br/>.

ARTEMISIA. Quem somos. Disponível em: $<$ https://artemisia.org.br/quemsomos/>.

ARTEMISIA. Sobre a Artemisia. Disponível em: $<$ http://artemisia.org.br/conteudo/artemisia/nosso-manifesto.aspx>.

APAEB - ASSOCIAÇÃO COMUNITÁRIA DE PRODUÇÃO E COMERCIALIZAÇÃO DO SISAL. Website. 2014. Disponível em: $<$ http://www.apaeb.com.br/empresa.html>.

ASSOCIATION EUROPEENNE DE THERAPIE COMMUNAUTAIRE INTEGRATIVE. Website. 2012. Disponível em: <https://www.aetci-a4v.eu/>.

ATHAYDE, Celso; MEIRELES, Renato. Um país chamado favela. São Paulo: Gente, 2014.

BARTOLOMÉ, Miguel Alberto. Las etnogénesis, viejos actores y nuevos roles en el escenario cultural y político. In: BARTOLOMÉ, Miguel Alberto. Procesos interculturales: antropología política del pluralismo cultural en América Latina. México: Siglo XXI, 2006.

BARTRA, Armando. El hombre de hierro. México: UACM, 2008. 
BATALLA, Guillermo Bonfil. Utopía y revolución. México: Nueva Imagen, 1981.

BELEZA NATURAL. Beleza Natural: uma fábrica de autoestima. Disponível em: <https://www.belezanatural.com.br/quem-somos>.

BENTES, Ivana. O que pode um funk? 2017. Disponível em: https://revistacult.uol.com.br/home/anitta-vai-malandra-ivana-bentes/. Acesso em: 25 jun. 2018.

. Respeitosamente vândala. Cult, n. 188, p. 7-10, 2014.

BIDASECA, Karina. Perturbando el texto colonial. Buenos Aires: SB, 2010.

BLACKROCKS. Nossa Missão. Disponível em: <http://www.blackrocks.com.br/\#nossa-missao>.

BRESSER-PEREIRA, Luiz. Nacionalismo no centro e na periferia do capitalismo. In: Estudos Avançados, n. 62, p. 30-49, 2008.

CANDIDO, Antonio. Literatura e sociedade. São Paulo: Nacional, 1967.

CARIELLO, Rafael. O antropólogo contra o Estado (Piauí). Uma (in)certa antropologia, 2013. Disponível em: <https://umaincertaantropologia.org/2014/01/06/o-antropologo-contra-oestado-piaui/>. Acesso em: 10 mai. 2018.

CARNEIRO, Maria J. Ruralidade: novas identidades em construção. Estudos Sociedade e Agricultura, Rio de Janeiro, n. 11, p. 90-107, out. 1998.

CAU - CONSELHO DE ARQUITETURA E URBANISMO DO BRASIL. Arquiteto do Brasil vence prêmio de Melhor Edifício Sustentável das Américas. 2018. Disponível em: <http://www.caubr.gov.br/arquiteto-do-brasilvence-premio-de-melhor-edificio-sustentavel-das-americas $>$.

CAVALCANTE, Ruth. Educação Biocêntrica Um portal de acesso à Inteligência Afetiva. Pensamento Biocêntrico, n. 6, p. 9-30, jul./dez. 2006. Disponível em: <http://www.pensamentobiocentrico.com.br/content/ed06_art01.php>.

CERBAMBU RAVENA - CENTRO DE REFERÊNCIA DO BAMBU E DAS TECNOLOGIAS SOCIAIS. Website. Disponível em: <https://www.cerbambu.org.br/>. 
CUFA - CENTRAL ÚNICA DAS FAVELAS. Fazendo do nosso jeito há 20 anos. 2019. Disponível em: <https://www.cufa.org.br/sobre.php>.

CLASTRES, Pierre. A sociedade contra o Estado. RJ: Francisco Alves, 1978.

CULTURA BIOCÊNTRICA. Educação Biocêntrica - teoria. 2007. Disponível em: <http://biodanca.blogspot.com/2007/08/educao-biocntrica-teoria.html>.

CUNHA, Manuela. História dos índios no Brasil. SP: Cia. das Letras, 1992.

DE ANDRADE, Oswald. Manifesto antropófago (1928). In: A utopia antropofágica. São Paulo: Globo, 1990.

DE CASTRO, Eduardo Viveiros. O recado da mata (prefácio). In: KOPENAWA, Davi; ALBERT, Bruce. A queda do céu. São Paulo: Cia. das Letras, 2015.

DE SOTO, Hernando. Economia subterrânea. Rio de Janeiro: Globo, 1987.

DIAS, Jaqueline Evangelista; LAUREANO, Lourdes Cardozo (Cords.) Farmacopéia Popular do Cerrado. Goiás: Articulação Pacari (Associação Pacari), 2009. Disponível em: <http://www.mma.gov.br/estruturas/sbf_agrobio/_publicacao/89_publicacao01 082011054912.pdf>.

EDUCAFRO. Website, 2019. Disponível em: <http://www.educafro.org.br/site/conheca-educafro/>.

EMPREGUE AFRO. Website. Disponível em: <https://empregueafro.com.br/wp/>.

ESCOBAR, Arturo. Sentipensar con la tierra. Medellin: UNAULA, 2014.

FANON, Frantz. Os condenados da terra. Rio de Janeiro: Civilização Brasileira, 1968.

FAVELA HOLDING. Nosso time. s. d. Disponível em: <https://www.fholding.com.br/>.

FIGUEIREDO FILHO, Paulo. Figueiredo estava certo. O Globo, 2014. Disponível em: <https://oglobo.globo.com/opiniao/figueiredo-estava-certo12799581>. Acesso em: 15 aug. 2018. 
FOIRN - FEDERAÇÃO DAS ORGANIZAÇÕES INDÍGENS DO RIO NEGRO. Website. Disponível em: <https:// foirn.org.br/>.

FRIEDMAN, Thomas. O Mundo é Plano. Rio de Janeiro: Objetiva, 2005.

F123. Website. Disponível em: <https://f123.org/>.

GASTROMOTIVA. Website, 2019. Disponível em: $<$ http://gastromotiva.org/>.

GONÇALVES, Marcos. 1922: a semana que não terminou. São Paulo: Cia das Letras, 2012.

HELLER, Agnes. O cotidiano e a história. Rio de Janeiro: Paz e Terra, 1985.

HIRSCHMAN, Albert. El avance en colectividad. México: FCE, 1986.

HOWARD, Ebenezer. Cidades-jardins de amanhã. São Paulo: HucitecAnnablume, $2^{\mathrm{a}}$ ed, 2002.

IEP - INSTITUTO ECUMÊNICO POPULAR L'AMIGO. Website. Disponível em: <https://ieplamigo.com.br/>.

IHU - INSTITUTO HUMANITAS UNISINOS. A transposição do Rio São Francisco: águas e falácias do desenvolvimento. 2017. Disponível em: <http://www.ihu.unisinos.br/78-noticias / 566590-a-transposicao-do-rio-saofrancisco-aguas-e-falacias-do-desenvolvimento >. Acesso em: 16 aug. 2018.

IHU - INSTITUTO HUMANITAS UNISINOS. Os novos demiurgos da nação. 2017. Disponível em: <http://www.ihu.unisinos.br/78-noticias/567524os-novos-demiurgos-da-nacao $>$.

LIMA, Flavia. Em retração, classes A e B ganham 464 mil negros. Folha de S. Paulo, 2018. Disponível em: <https://www1.folha.uol.com.br/mercado/2018/08/em-retracao-classes-a-e-bganham-464-mil-negros.shtml>.

LISBOA, Armando. Mercado solidário. In: A outra economia. Porto Alegre: Veraz, 2003.

Economia, idolatria, charlatanice. Studium, Curitiba, ano 8, n. 13, 2014. Disponível em: <https://claretiano.edu.br/revista/66/teologia-e-questoes-deidolatria>. 
LISBOA, João Francisco. Acadêmicos indígenas em Roraima e a construção da interculturalidade indígena na universidade: entre a formação e a transformação. 2017. Tese (Doutorado em Antropologia). Instituto de Ciências Sociais, Universidade de Brasília, Brasília.

MARIÁTEGUI, José. Textos básicos. Lima: FCE, 1991.

MARICATO, Ermínia. "Os prisioneiros da especulação imobiliária” (entrevista). In: Caros Amigos, mai. 2010.

MARQUES, Claudio. Artemisia lança curso online em negócios de impacto social. Estadão, 21 de outubro de 2014. Disponível em: https://economia.estadao.com.br/blogs/sua-oportunidade/artemisia-lanca-cursoonline-em-negocios-de-impacto-social/. Acesso em: 27 out. 2019.

MAX-NEEF, Manfred; et al. Desarrollo a escala humana. Santiago: CEPAUR, 1986.

MÉSZÁROS, István. Para além do capital. São Paulo: Boitempo, 2002.

MOC - MOVIMENTO DE ORGANIZAÇÃO COMUNITÁRIA. Website, 2015. Disponível em: <https://www.moc.org.br/>.

MOVIMENTO PVNC - PRÉ-VESTIBULAR PARA NEGROS E CARENTES. Website. Disponível em: $<$ http://www.sentimentanimalidades.net/pvnc/index.htm>.

MOVIMENTO SAÚDE MENTAL COMUNITÁRIA. Website. Disponível em: $<$ https://msmc.org.br/>.

MULTIMISTURA - Dra. Clara Brandão: Biografia. Disponível em: <http://multimistura.org.br/biografia.htm>. Acesso em: 03 mai. 2018.

MUNARO, Juliana. Startup oferece cursos de inglês em comunidade a preços acessíveis. G1, 2017. Disponível em: $<$ http://g1.globo.com/economia/pme/pequenas-empresas-grandesnegocios/noticia/2017/12/startup-oferece-cursos-de-ingles-em-comunidadesprecos-acessiveis.html>.

NEGRI, Antonio; COCCO, Giuseppe. Glob(AL). Rio de Janeiro: Record, 2005.

NEGRI, A.; HARDT, M. Império. São Paulo: Record, 2001. 
NOBRE, Marcos. Depois da 'formação. Piauí, n. 74, p. 74-77, 2012.

PERLMAN, Janice. O mito da marginalidade. Rio de Janeiro: Paz e Terra, 1977.

PERRONE-MOISÉS, Leyla. Vira e mexe, nacionalismo. São Paulo: Cia. das Letras, 2007.

PROTAGONIZO.COM. Website. Disponível em: <https://www.protagonizo.com/>.

QUIJANO, Aníbal. La economía popular y sus caminos en América Latina. Lima: Mosca Azul, 1998.

QUIJANO, Aníbal. "Colonialidad del poder, eurocentrismo y América Latina”. In: LANDER, E. (comp.). La colonialidad del saber: Eurocentrismo y ciências sociales. Buenos Aires: CLACSO, 2000.

QUIJANO, Aníbal. Sistemas alternativos de produção? In: SANTOS, Boaventura de Sousa (Org.). Produzir para viver. Rio de Janeiro: Civilização Brasileira, 2002.

REDAÇÃO. Conjuntura da Semana Especial: A reorganização do capitalismo brasileiro. EcoDebate, 2009. Disponível em: <https://www.ecodebate.com.br/2009/11/14/conjuntura-da-semana-especial-areorganizacao-do-capitalismo-brasileiro/>. Acesso em: 15 aug. 2018.

REDE DE AGROECOLOGIA ECOVIDA. Website. Disponível em: $<$ http://ecovida.org.br/>.

SACHS, Ignacy. Desenvolvimento includente, sustentável sustentado. Rio de Janeiro: Garamond, 2008.

SANTOS, Marize; FONSECA, Said. Farmácias Vivas. In: BRASIL. Ministério da Saúde. Praticas integrativas e complementares: plantas medicinais e fitoterapia na Atenção Básica. 2012. Disponível em: <https://cursos.atencaobasica.org.br/sites/default/files/farmacias_vivas_0.pdf $>$. Acesso em: 10 mai. 2018.

SANTOS, Milton. A natureza do espaço. São Paulo: Hucitec, 3. ed., 1999. 
SERTA - SERVIÇO DE TECNOLOGIA ALTERNATIVA. Website, s. d. Disponível em: <http://www.serta.org.br/inicial/>.

SILVA, Graziano da. A modernização dolorosa. Rio de Janeiro: Jahar, 1982.

SINGER, Paul. A recente ressurreição da economia solidária no Brasil. In: : SANTOS, Boaventura de Sousa (Org.). Produzir para viver. Rio de Janeiro: Civilização Brasileira, 2002.

SUZUKI, Natália. $\mathbf{7 5 0}$ organizações do semi-árido dizem 'não' à transposição. Repórter Brasil, 2006. Disponível em: <https://reporterbrasil.org.br/2006/12/750-organizacoes-do-semi-arido-dizemnao-a-transposicao/ $>$.

TAWNEY, Richard. A religião e o surgimento do capitalismo. São Paulo: Perspectiva, 1971.

TODOROV, Tzvetan. A vida em comum. Campinas: Papirus, 1996.

UFRR - Universidade Federal de Roraima. Instituto Insikiran de Formação Superior Indígena - Website, s. d. Disponível em: < http://ufrr.br/insikiran/>.

UNGER, Roberto. Depois do colonialismo mental. São Paulo: Autonomia Literária, 2018.

VALE DO DENDÊ. Website. Disponível em: $<$ http://www.valedodende.org/>.

VARGAS LHOSA, Mário. Sabres e utopias. Rio de Janeiro: Objetiva, 2010.

VEIGA, José Eli. Cidades imaginárias. Campinas: Autores Associados, 2002.

ZAGO, Nadir. Cursos pré-vestibulares populares: limites e perspectivas. Perspectiva, v. 26, p. 149-174, 2008.

Endereço para correspondência:

Armando de Melo Lisboa-amelolisboa@gmail.com

R. Eng. Agronômico Andrei Cristian Ferreira, s/n, Trindade

88.040-900 Florianópolis/SC, Brasil 